\title{
GÜMÜŞHANE'DE PEK BILINMEYEN İKI MEZAR ANITI*
}

\author{
KASIM İNCE **
}

Burada tanıtılmaya çalışılacak olan iki mezar anıtı Gümüşhane'nin merkezinde olmayıp; bunlardan Anonim Kümbet (Pir Ahmet Türbesi) merkeze bağlı Pirahmet Köyü'nde, diğeri, Çağırgan Baba Türbesi ise, Tekke Beldesi'ndedir. Bu iki mezar anıtının bulunduğu yerlerden Tekke Beldesi Gümüşhane-Bayburt yolunda; Pirahmet Köyü ise Gümüsşhane-Kelkit yolu üzerinde, Tekke Beldesi'ne $5 \mathrm{~km}$. mesafededir (1. Harita).

Her iki yerleşim yerinin Gümüşhane'ye bağlı olması, tabiî olarak Gümüşhane tarihi üzerinde durmayı gerektirir. Ancak, eski Gümüşhane'nin, Harşit Vadisi'ne doğudan ilhak eden Musalla Deresi yamaçlarında olması', Gümüşhane'nin şimdiki konumunu 1918'den sonra kazanmış olması ${ }^{2}$, özellikle Türk tarihiyle ilgili olaylar bakımından, tarihî bilgilerin, bölge olarak, Bayburt'un tarihi ile birlikte ele alınmasının daha uygun olacağını düșündürmüștür. Çünkü, Bayburt, bölgenin Türkleşmesinde önemli rol oynamış bir merkezdir.

İki vilâyetimiz de Trabzon'dan Tebriz'e kadar uzanan "İran Transit Yolu" adı verilen Trabzon-Erzurum Caddesindedirler ${ }^{3}$.

- Konuya dikkatimi çeken ve yardımlarım esirgemeyen Selahattin Tozlu ile mezar anıtlarının kitabesinin okunmasındaki yardımlarından dolayı Selami Bakırcı'ya teşekkürü bir borç bilirim.

.* Pamukkale Üniversitesi, Fen-Edebiyat Fakültesi, Arkeoloji ve Sanat Tarihi Bōlümū, Sanat Tarihi Anabilim Dalı.

1 Besim Darkot, "Gümüşhane" maddesi, İA., IV. C., İstanbul, 1964, 836. s.; Selahattin Tozlu, "XIX. Asırda Gümüşhane Şehri ve Bahçeleri", Kültür Vadisi Gümüşhane, 6. Sayı, İstanbul, 1995, $22 \mathrm{~s}$.

2 Besim Darkot, a.g.m., 836. s.; Gülyüz (Akagün) Uslu, Gümüşhane Çevresinin Tarihi ve Sanat Eserleri, İstanbul, 1980, 8. s.; Metin Tuncel, "Türkiye'de Yer Değiştiren Şehirler ve Gümüşhane Örneği", Geçmişte ve Günümüzde Gümüşhane Sempozyumu (13-7 Haziran 1990). Ankara, 1991, 33. s.

${ }^{3}$ Besim Darkot, a.g.m., 836. s.; "Bayburt" maddesi, IA., II. C., İstanbul, 1961, 365. s.; Metin Tuncel, a.g.m., 33. s. Erzurum-Trabzon yolunun Tanzimaun ilk yıllarına kadar, yaylalardan geçtiği, daha sonra şimdiki güzergâhın kullanıldığı anlaşılmışur. M. Fahrettin Kırzıoğlu, "Osmanlı Tapu-Tahrir Ve Mühimme Defterlerinde Gümüşhane Bölgesi Türk Boy/Oymak Haturaları Ve Madenleri Üzerine Hükümlerden Örnekler" Geçmişte Ve Günümüzde Gümüşhane Sempozyumu (13-17 Haziran 1990), Ankara 1991, 73. s. 
Türklerin, Anadolu'da, ilk fethettikleri yerlerden biri de Bayburt'tur' 1071 Malazgirt Zaferi'nden sonra, Bayburt'un, bir ara, Danişmendliler'in elinde kaldığından söz edilmektedir ${ }^{5}$. Ancak Bayburt ve çevresi, bu topraklar üzerinde kurulan ilk beylikler döneminde, merkezi Erzurum olan Saltukogullari'nın elinde bulunmuştur ${ }^{6}$. Saltuklular'la, "merkezi Erzincan'da bulunup, (başlangıçta) Trabzon, Harşit Çayı (Torul ve Gümüşhane dahil) ile Kelkit Çayı boyu, hatta Tunceli ve Palu kesimiyle Divriği'yi ihtiva eden Mengücüklü Emirliği, birbirine komşu bulunuyordu"7. Konumuz olan iki mezar anıtının bulunduğu yerleșim yerlerinin, bu dönemde kimin elinde bulunduğu pek açık değildir. Belki de Saltuklular'la Mengücüklüler'in sınır bölgesinde kalıyorlardı. Bu sıralarda Gümüşhane'nin Türkler tarafından fethedilmediği anlaşılmaktadır. Danişmendliler'in; Niksar, Malatya, Sivas, Amasya ve Merzifon kesimlerinde hüküm sürdükleri ve eserlerini, daha çok, o bölgelerde ortaya koydukları bilindiğine göre Gümüşhane ve Bayburt'la ilgilerinin çok kısa sürdüğü anlaşılmaktadır. Dolayısıyla bu bölgenin daha çok Saltuklular ve Mengücüklüler arasında kaldığını kabul edebiliriz.

Bir ara, Trabzon İmparatoru Alexis Comnene'nin kumandan Thedore Gabras tarafindan zaptedilmekle birlikte, Bayburt, Malazgirt Zaferi'nden XIII. yüzyılın başlarına kadar Saltuklular'ın hakimiyetinde kalmıştır ${ }^{8}$. Bu arada Gümüşhane, 1204'de Bizanslılardan, Trabzon-Rum İmparatorluğu'nun eline geçmiştir ${ }^{9}$. Bayburt ise Saltuklular'ın, 1202 yılında, Konya Selçuklu Sultanlığı tarafindan ortadan kaldırılmasına kadar, onların elinde kalmıştır ${ }^{10}$.

\footnotetext{
${ }^{4}$ Osman Turan, "Bayburt" Maddesi, IAA., II. C., İstanbul, 1961, 365. s.; Selçuklular Tarihi Ve Türk İslâm Medeniyeti, İstanbul, 1966, 107. s.

${ }^{5}$ A. Şeref Beygu, Erzurum Tarihi Antları Kitabeleri, İstanbul, 1936, 248. s.; Osman Turan, a.g.m., 365. s. Doğu Anadolu Türk Devletleri Tarihi, 40. s.; Erdoğan Merçil, Müslüman Türk Devletleri Tarihi, İstanbul, 1985, 253. s. Enver Konukçu, "Bayburt Tarihi" Türk Tarihinde Ve Kültürūnde Bayburt Sempozyumu (23-25 Mayıs 1988), Erzurum, 1989, 11. s.; İsmet Miroğlu, "Bayburt" maddesi, TDV. IA., V.C., İstanbul, 1992, 226. s.

Ancak, Danişmendliler hakkunda kapsamlı bir makale yazan Yınanç, bōyle bir bilgiden bahsetmemektedir. M. Halil Ynanç, "Danişmedliler" maddesi, IA., III., C., İstanbul, 1963, 468479. s.

${ }^{6}$ A. Şeref Beygu, a.g.e., 248. s.; Faruk Sümer, "Saltuklular" Selçuklu Araşurmalan Dergisi, III, Ankara, 1971, 415. s.; Osman Turan, a.g.m., 365. s.; Doğu Anadolu Türk Devletleri Tarihi, İstanbul, 1973, 3. s.; Erdoğan Merçil, a.g.e., 283. s.

${ }^{7}$ M. Fahrettin Kırzıoğlu, a.g.m., 70. s.

${ }^{8}$ Osman Turan, a.g.m., 365. s., İsmet Miroğlu, a.g.m., 226. s.

${ }^{9}$ Gülyūz Uslu, "Gümüşhane'nin Tarihçesi Ve Turistik Değerleri", Geçmişte Ve Günümüzde Gūmūşhane Sempozyumu (13-17 Haziran 1990), Ankara, 1991, 42. s.

${ }^{10}$ Faruk Sümer, a.g.m., 422. s.; Erdoğan Merçil, a.g.e.,284. s.; İsmet Miroğlu, a.g.m., 226. s.; Enver Konukçu, a.g.m., 11. s.; Selçuklulardan Cumhuriyete Erzurum, Ankara, 1992, 26. s.
} 
Selçuklu sultanlarından Alaeddin Keykûbat zamanında (1220-1237) Konya'ya bağlanan Bayburt, Kösedağ Savaşı'nın (1243) ardından, Anadolu Moğollarının eline geçse de, Selçuklulara bağlı kalmıştır" ${ }^{\prime \prime}$. Son İlhanlı hükümdarı Ebu Said Bahadır Han'ın ölümünden sonra (1334), Bayburt, Gümüşhane ile birlikte Celayirlilerin eline geçmiştir ${ }^{12}$. Daha sonra Bayburt ve çevresinde bir müddet, Eretnaoğullarının hakimiyeti görülmektedir ${ }^{13}$. Ayrıca, Erzincan beyi Mutahharten de Bayburt ve çevresini bir süre elinde tutmuştur ${ }^{14}$. 1394'te, Kadı Burhaneddin zamanında, Akkoyunlu beylerinden Kutlu Bey'in oğlu Ahmed Bey'in ${ }^{15}$ yardımıyla, kent, Mutahharten'den alınmış ve ardından, Kadı Burhaneddin tarafından Akkoyunlulardan Ahmed Bey'e ikta olarak verilmiştir ${ }^{16}$. Bayburt'a bağlı Sinür (Çayıryolu) ve Pulur köylerini merkez yaparak büyüyen ve bir devlet olan Akkoyunlular, 1473 yılında, Osmanlılarla yaptukları Otlukbeli Savaşı'nda mağlup olmuşlardır ${ }^{17}$. Bu arada, 1479 yılında, Torul ve Gümüşhane Osmanlılar tarafindan fethedilmiştir ${ }^{18}$. Akkoyunlular, Otlukbeli'nde yenilmelerine rağmen, bir süre daha Bayburt'a hakim olmuş-

11 Osman Turan, a.g.m., 365. s.; İsmet Miroğlu, a.g.m., 226. s.

12 Osman Turan, a.g.m., 366. s. Doğu Anadolu Türk Devletleri Tarihi, 41.s.

${ }^{13}$ A. Şeref Beygu, a.g.e., 248. s.; Osman Turan, a.g.m.,366. s.; Doğu Anadolu Türk Devletleri Tarihi, 45. s.; Enver Konukçu, a.g.m., 16. s.; İsmet Miroğlu, a.g.m., 226. s.

${ }^{11}$ A. Şeref Beygu, a.g.e., 248. s.; Osman Turan, a.g.m., 366. s.; Doğu Anadolu Türk Devletleri Tarihi, 45. s.; Enver Konukçu, a.g.m., 16. s.; İsmet Miroğlu, a.g.m., 226. s.

${ }^{15}$ Ahmet Bey'in mensup olduğu Akkoyunlular, Oğuzların Bayındır boyundandırlar. M. Halil Yınanç, "Akkoyunlular" maddesi İA.., I. C., İstanbul, 1965, 255. s.; Osman Turan, Doğu Anadolu Türk Devletleri Tarihi, 45. s.; İ. Hakkı Uzunçarşılı, Anadolu Beylikleri Ve Akkoyunlu, Karakoyunlu Devletleri, Ankara, 1984, 188. s.; Bahaeddin Ögel vd., Türk Milli Bütünlüğü İçinde Doğu Anadolu, Ankara, 1992, 23. s.; Ahmed Bey'in babası, Kutlu Bey'in mezarı, Bayburt'a bağlı Sinür Köyü'ndedir. A. Şeref Beygu, a.g.e., 249-250. s.; Ali Kemali, Erzincan, (Basımyeri yok), 1932, 79. s. 1. dipnot; M. Halil Yınanç, a.g.m., 255. s.; M. Fahrettin Kırzıoğlu, Osmanlıların Kafkas Ellerini Fethi, Ankara, 1976, 36. s.; Gönül Güreşsever-Ara Altun, "Bayburt'un Kōylerinde Türk Mimarî Eserleri", Sanat Tarihi Yıllığı, III, İstanbul, 1970, 44-46. s.; Metin Sözen, Anadolu'da Akkoyunlu Mimarîsi, İstanbul, 1976, 145. s.; I. Hakkı Uzunçarşıll, a.g.e., 188. s.; Yaşar Yücel, Anadolu Beylikleri Hakkında Araşurmalar, II, Ankara, 1991, 194. s.; Bahaeddin Ögel vd., a.g.e., 23. s.

${ }^{16}$ Aziz B. erdeșir-i Esterâbadî, Bezm ü Rezm (Çeviren: Mürsel Öztürk), Ankara, 1990, $342-$ 352. s.; M. Halil Yınanç. a.g.m., 255.; İsmet Miroğlu, XVI. Yüzyılda Bayburt Sancağı, İstanbul, 1975, 14. s.; a.g.m., 226. s.

${ }^{17}$ M. Fahrettin Kırzıoğlu, a.g.e., 193. s.; İ. Hakkı Uzunçarşılı, a.g.e., 193. s.; Osmanlı Tarihi, II. C., Ankara, 1988, 101. s.; Enver Konukçu, a.g.e., 116. s.

${ }^{18}$ M. Fahrettin Kırzıoğlu, a.g.e., 38-39. s.; "921 h. / 1516 Trabzon Mufassal Defterinde, Torul'un köyleri içinde ve bütūn Trabzon'un güneyindeki bölgelerde Kōgans/Kuvans Kalesi'nin adının geçmemesi, Harşit Çayı başlarında ve Gümüşhane'nin doğu yukarısındaki bu bōlgenin, 1479 Osmanlı fethinden önce Torul (Kabasitanlı) Beyliği dışında ve Akkoyunluların elinde bulunmasındandır. M. Fahrettin Kırzıoğlu, a.g.e., 49. s. 
larsa da, kent, Safevîlerin eline geçmiş ve kısa süre onların elinde kalmıştır ${ }^{19}$. Şehir, Safevilerin elinde iken, Trabzon sancak beyi olan Şehzade Selim, bu bölgeye akınlarda bulunmuştur ${ }^{20}$. Bununla birlikte, Sultan II. Beyazid'in, Yavuz Sultan Selim'i takdir yerine, onun akın ve fetihlerini hoşgörmediği, bu yüzden, İstanbul'dan gönderdiği fermanlarla, Safevilerden alınan Erzincan ile Bayburt'un, Kemah'in ve Atabeklerden zaptedilen Kökez (Kökans) ${ }^{21}$ ile İspir'in boşaltularak geri verildiği anlaşılmaktadır ${ }^{22}$. Fakat Bayburt ve çevresi, Caldıran Savaşı (1514) sonunda, kesin olarak, Osmanlılar tarafindan fethedilmiştir ${ }^{23}$. Bu arada Bayburt Sancağı, Erzincan Vilâyeti adıyla kurulan yeni bir uç beyliğine, Kökans-Kökez-Kökaz-Köğans-Kovans Nahiyesi de Bayburt Sancağına bağlanmıştır ${ }^{24}$. Bizi ilgilendiren iki mezar anıtı, Bayburt'a bağlı Kovans Nahiyesi dahilinde kalmaktadır ${ }^{25}$. Bu nahiye bir ara kaza olmuş, fakat tekrar nahiye olarak değiştirilmiştir ${ }^{26}$.

1516-1518'de Kovans kazasının 66 köyü, 6 mezraası bulunduğu, 1520 yılında köy sayısının 69'a, mezraa sayısının 7'ye yükseldiği belirlenmiştir. 1530 'da ise köy sayısı 69 iken, mezra sayısı 20 olarak tespit edilmiştir ${ }^{27}$. Pirahmet Köyü, Kovans kazasının köylerinden biri olarak görülmektedir ${ }^{28}$, Tekke'nin adı Selseke biçiminde geçmemektedir ${ }^{29}$.

19 Osman Turan, a.g.m., 366. s.; İsmet Miroğlu, a.g.m., 226. s.

${ }^{20}$ Osman Turan, a.g.m., 366. s.; İsmet Miroğlu, a.g.m., 226. s.

${ }^{21}$ Erzurum-Tortum civarında bir köy ve kaledir. Kovans'la ilgili değildir.

${ }^{22}$ M. Fahrettin Kırzıoğlu, a.g.e., 100.s.

${ }^{23}$ Osman Turan, a.g.m., 366. s.; Selahattin Tansel, Yavuz Sultan Selim, Ankara, 1969, 70 71. s.; M. Fahrettin Kırzıoğlu, "1522 (h. 928) Yılında Issız Ve Harap Duran Erzurum Bölgesi (Nahiye)leri", Tarih Yolunda Erzurum, 5-6. Sayı, İstanbul, 1960, 9. s.; a.g.e., 100., 119. s.; İ. Hakkı Uzunçarşılı, Osmanlı Tarihi, II. C., 271., 448. s.; İsmet Miroğlu, a.g.e., 14-15. s.; a.g.m., 226. s.; T. Erdoğan Şahin, Erzincan Tarihi, II. C., Erzincan, 1987, 21-22. s.

${ }^{24}$ M. Fahrettin Kırzıoğlu, a.g.e., 119. s.; Bayburt Sancağı, 1516-1518 yllarında; Bayburt, Kelkit, Sadak, Kovans, Tercan-ı Ulya ve Tercan-1 Süfla nahiyelerinden meydana gelmektedir. İsmet Miroğlu, a.g.e., 25. s.; Kemah Sancağı Ve Erzincan Kazası (1520-1566), Ankara, 1990, 19. s.; T. Erdoğan Şahin, a.g.e., II. C., 39. s.

${ }^{25}$ Kovans, şimdi, Gümüşhane iline bağlı Kale ilçesinin eski adıdır. Dündar Aydın, Erzurum Beylerbeyiliği Ve Teşkilâtu Kuruluşu Ve Genişleme Devri (1535-1566) (Yayınlanmamış Doktora Tezi), Erzurum, 1972, 111. s., 23. dipnot; İsmet Miroğlu, XVI. Yüzyılda Bayburt Sancağı, 25. s.

${ }^{26}$ M. Fahrettin Kırzıoğlu, a.g.e., 120. s.; 70. dipnot, 127. s.; Dündar Aydın, a.g.tez, 159-160. s.; İsmet Miroğlu, XVI. Yüzylda Bayburt Sancağı, 26-27. s.

${ }^{27}$ İsmet Miroğlu, XVI. Yüzyılda Bayburt Sancağı, 33. s.; M. Fahrettin Kırzıoğlu, "Osmanlı Tapu-Tahrir ve Mühimme Defterlerinde Gümüşhane Bölgesi Türk Soy/Oymak Hauraları ve Madenleri Üzerine Hükümlerden Örnekler", Geçmişte Ve Günümüzde Gümüşhane Sempozyumu (13-17 Haziran 1990), 71. s.

28 "Pirahmet: 1516 'da 4 sipahi; 1530 'da 1 h; 159l'de 15 nefer müslüman, 4 nefer hıristiyan vardı. Mahsulleri, buğday, arpa ve bostan ürünlerinden ibaret olup, hasılı 1516'da 2.000 , 1530 'da $1.500,1591$ 'de 3.000 akça idi. Burada bir de değirmen bulunmakta idi." İsmet Miroğlu, XVI. Yüzylda Bayburt Sancağı, 91 . s.

${ }^{29}$ BOA., TD. 60,228 . s. 
1535 yılında Erzurum Vilâyeti kurulunca buraya, Trabzon Sancağı ile birlikte Gümüşhane kesimi de bağlanmıştır ${ }^{30}$. Aynı şekilde Erzurum'a bağlanan Bayburt Sancağı, 1551'den sonra kaza, 1631'de ise liva olmuştur ${ }^{31}$. Bu tarihten XIX. yüzyıla kadar buralarda önemli bir olay olmamıştır ${ }^{32}$. 1828-1829 ${ }^{33}$ ve 1916-1918 yıllarında her iki ilimiz dolayısıyla iki köy de Rus işgaline maruz kalmıştır ${ }^{34}$. Daha sonra Trabzon Vilâyetine bağlanan Gümüşhane livası, 1870 'de bu vilâyetten ayrılarak müstakil mutasarrıflık olmuş, 20 Nisan 1924 tarihli Teşkilât-1 Esasîye Kanunu'nun 89. maddesi gereğince vilâyet halini almışur $^{35}$. Bayburt ise 1927 'de, bir kaza olarak Gümüşhane'ye bağlanmış, 21 Haziran 1989 ve 20202 sayılı resmi gazetede yayınlanan 3578 numaralı kanunla vilâyet olmuştur.

\section{PIRAHMET KÖYÜ'NDE ANONIM KÜMBET (PIR AHMET TÜRBESI)}

Yeri: Köyün içinden geçen Gümüşhane-Erzincan karayolunun güney tarafında, köy camisinin doğusundaki mezarlık içinde bulunmaktadır.

Mimarî Özellikleri: Bir köy mezarlığındaki bu eser; sade, küçük ve gösterişsiz haliyle dikkatleri fazlaca çekmemiştir. Anıt, kare prizmal bir gövdenin piramidal külâhla örtülmesinden ibaret taş bir yapıdır (1. Resim). İki kath yapının; toprak seviyesinden eşikle ayrılmış üst katına, kilit taşında yarım yuvarlak çıkıntılar bulunan basık kemerli kapıdan girilir (2. Resim). Cevresinde ve bulunduğu cephede herhangi bir bezemenin olmadığı kapıdan içeri geçilince, yaklaşık $2.70 \times 2.70 \mathrm{~m}$. ölçülerindeki, kare plânlı küçük üst kata girilir ${ }^{3 i}$ (1. Çizim). Harçla sıvanarak açık mavi renkli kireçle badanalanmış olan iç mekânın, yarım küre olan üst örtüsü de aynı şekilde sıvanarak badanalanmışur. Üst kata ışık sağlayan iki mazgal pencereden biri güney, diğeri doğu du-

${ }^{30}$ M. Fahrettin Kırzıoğlu, "Osmanlı Tapu-Tahrir ve Mühimme Defterlerinde Gümüşhane Bölgesi Türk Boy/Oymak Hatıraları Ve Madenleri Üzerine Hükümlerden Örnekler", Geçmişte Ve Günümüzde Gümüșhane Sempozyumu, 73, s.

31 İsmet Miroğlu, XVI. Yüzyılda Bayburt Sancağı, 25. s.

32 İsmet Miroğlu, XVI. Yüzyıllarda Bayburt Sancağı, 226. s.

33 İsmet Miroğlu, a.g.m., 226, s.

31 İsmet Miroğlu, a.g.m., 226. s.; Gümüşhane İl Yıllığı 1973, Ankara, 1974, 2. s.; 1916-1918 vıllarındaki Rus işgali sırasında Gümüşhane ve çevresindeki Ermeni zulmünden Pirahmet ve Tekke köyleri de zarar gōrmüştür. Selahattin Tozlu, "Gümüşhane ve Cevresindeki Ermeni Hareketleri", Geçmişte Ve Günümüzde Gümüşhane Sempozyumu, 103-104. s.

35 Ercüment Kuran, "Cumhuriyet Devrinde Gümüșhane'nin Sosyal, Ekonomik ve Kültürel Gelişmesi", Geçmişte Ve Günümüzde Gümūşhane Sempozyumu, 23. s.

3i Yapmmn iç ölçūleri; kuzey tarafı $2.69 \mathrm{~m}$., bau tarafı $2.72 \mathrm{~m}$.. güney tarafı $2.70 \mathrm{~m}$.. doğu tarafi $2.73 \mathrm{~m}$. dir. 
varında açılmıştır. Mekânın batı duvarının yukarısında, ortalanarak konulmuş, yapıyla hiç bir ilgisi olmayan kitabe bulunmaktadır. Üst kat girişinin eşiğinden $0.21 \mathrm{~m}$. sonra; uzunlamasına düzenlenmiş, $0.80 \times 0.53 \mathrm{~m}$. ölçülerindeki açıklık, cenazeliğin girişidir ${ }^{37}$. Üst katun taş döşemeli zeminine daha sonra ince bir harç dökülmüştür. Bu harç da yer yer tahrip olmuş durumdadir.

Yukarıda ölçülerini verdiğimiz üst kattaki açıklıktan; yükseklikleriyle derinlikleri farklı ve düzgün olmayan taşlardan yapılmış dört basamaklı merdivenle cenazeliğe inilir. Cenazelik, yaklaşık olarak 2.20x2.20 m. ölçülerinde kare bir alanı kapsar ${ }^{38}$. Duvarlanı moloz taşlarla örülü olan bu kısmın üst örtüsü, sivri uçları aşağıya gelecek biçimde, moloz taşlarla gerçekleştirilmiştir. $\mathrm{Bu}$ örtü biçimi gerçek anlamda olmasa da, manastur tonozunun varyasyonu olarak adlandırılabilir ${ }^{39}$. İçinde, $1.68 \times 0.72 \mathrm{~m}$. ölçülerinde, kime ait olduğu bilinmeyen ahşap bir sandukanın ${ }^{40}$ bulunduğu cenazeliğin zemini, sıkışurılmış topraktur.

Yaklaşık olarak $4.00 \times 4.00 \mathrm{~m}$. ölçülerindeki kare prizmal gövdenin, dört yüzeyli piramidal külâhla örtülmesiyle dış görünüşünü kazanmış olan yapının, cephelerinin hiç birinde bezemeye işaret edebilecek iz yoktur ${ }^{41}$. Piramidal külâhın, sonradan yapıldığı belli olan harç kaplamanın alundaki üst örtüsünün taşlarının, cenazeliğin üst örtüsünde kullanılan moloz taşlardan olduğu anlaşılmakktadır. Bugün harap durumdaki üst örtünün tepesine konulmuş olan taş alemin orijinal olduğu konusunda şüpheliyiz.

Tarihçesi: Banisi ve mimarı belli olmayan kümbetin, kendisine ait bir kitabeye rastlanamamışur.

Yapı üzerinde, yukarıda bahsettiğimiz, eserle doğrudan ilgisi olmayan bir kitabe vardır. Siyah mermer üzerine, dört satur olarak, sülüs hatla, Arapça yazılmış, $0.76 \times 0.43 \mathrm{~m}$. ölçülerindeki kitabe şöyledir (3. Resim):

\footnotetext{
${ }^{37} \mathrm{Bu}$ açıklığın kenarlarımın alt kısmındaki; 0.02 metrelik çıkınular, açıklığın ũzerinin seyyar bir kapakla kapatuldığının işaretidir.

${ }^{38}$ Cenazeliğin kuzey tarafı $2.18 \mathrm{~m}$., bat tarafı $2.22 \mathrm{~m}$., güney tarafı $2.20 \mathrm{~m}$., doğu tarafı $2.24 \mathrm{~m}$. ölçülerindedir.

${ }^{39}$ Bu örtü biçimi, plândan, her ne kadar aynalı tonoz olarak algılansa da aynalı tonoz değildir. Cenazeliğin duvarları yükselirken, hafifçe daraltulmış, üst kısma dỏnüş sağlandıktan sonra dủz bir örtū oluşturulmuştur. Üst òrtünūn oluşumu, manasur tonozunun varyasyonu olarak adlandırmamıza temel teşkil etmektedir.

${ }^{40}$ Sanduka, şu andaki durumuna kỏylüler tarafından yapılan onanmlarla kavuşmuştur.

41 Yapının dış ôlçüleri; kuzey tarafta $3.99 \mathrm{~m}$., bat tarafta $4.01 \mathrm{~m}$., güney tarafta $3.97 \mathrm{~m}$., doğu tarafta $4.01 \mathrm{~m}$. dir.
} 
1. satur:

$$
\text { هذا ذكر ما و تف و احسن في سبيل الا عز الاكرم }
$$

2. saur:

$$
\begin{aligned}
& \text { رلا بـنون الا من أ تى الله بتلب سليم اجتمع................. } \\
& \text { المدعو..... عن العليا و السفلى مع و بينهما سد لـد } \\
& \text { الطاحو نح الكاننة في مز رعة ............ }
\end{aligned}
$$

3. satır:

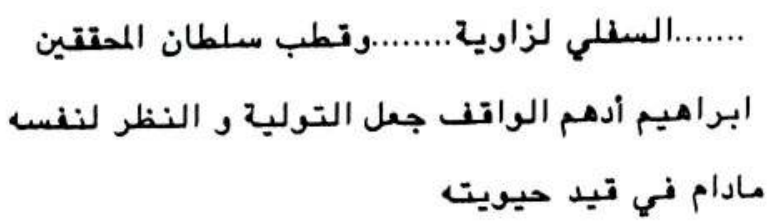

4. satur:

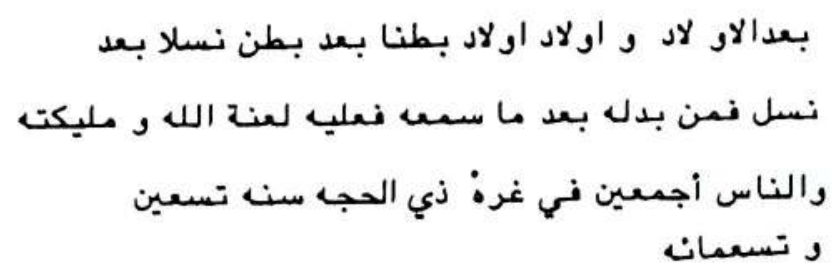

1. satur: Hâzâ zikru mâ vakafe ve ahsene fî sebîli'l-eazzi'l-ekrem, iftiharü'ssülehâ Derviş bin Murâd el-merhûm .el-Edhemî li-yevmin lâ yenfeu ma'lûn

2. satur: velâ benûn illâ men ete'llâhe bi kalbin selîm içteme'a ....el-med'uvvü ani'l-'ulyâ ve's-süflâ ma'a ve beynehumâ seddü'ttâhuneti el kâineti fî mezra'ati

3. saur: ve kutbü sultâni'l muhakkikîn İbrahim Edhem ..............el-vâkıf ce'ale et-tevliyete ve'n-nazar li-nefsihi mâ-dâme fi kaydı hayeviyetihi

4. satur: Ba'de'l-evlâd ve evlâdı evlâd batnen ve ba'de batnin neslen ba'de neslin femen beddelehû ba'de mâ semi'ahu fe aleyhi la'netullahi ve melâiketihi ve'n-nasi ecma'în fì gurret-i zilhicce sene us'în ve us'a mie 
Anlaşılacağı üzere yukarıdaki kitabe bir vakıf kitabedir. Ancak bu kitabede kümbet veya türbe lafzı geçmemektedir. Buna işaret eden herhangi bir ip ucu da yoktur. Dolayısıyla kitabe mezar anıtının üst katında bulunsa da, bununla ilgili olarak görülüp değerlendirilemez. $O$ halde kitabe, bir başka yerden getirilerek şimdiki bulunduğu yere yerleştirilmiş olmalıdır. Şunu da ilâve etmek gerekir ki, köyden hiç kimse, kitabenin başka yerden buraya getirilerek yerleştirilip yerleştirilmediği konusunda, bize, hiç bir bilgi verememiştir. Dolayısıyla kitabenin, kümbetin tarihlendirilmesinde fazla dikkate alınması da düşünülemez.

Bu durumda, eserin tarihlendirilmesinde, tarihî bilgilerin önemi artmaktadır. O nedenle de, eserlerin bulunduğu yerlerin tarihî-coğrafyasının ayrıntılı olarak ele alınmasının gerekliliği ortaya çıkmaktadır. Gümüşhane tarihi, şimdiki idarî teşkilâtla, paralellik arzedecek şekilde incelenemez. Zira, bölgenin hem Osmanlı öncesi tarihi, hem de Osmanlı fethi ve müteakip dönemi birbirinden farklıdır. Gümüşhane halkı arasında halen yaşayan bir tabir de bunun adeta delilidir. Halk, vilâyeti "Aşağı Dere" ve "Yukarı Dere" diye anmaktadır. Gerçekten de Vavuk Dağı'ndan Zigana'ya kadar bir vadiden ibaret olan şehrin tamamı hakkında söylenen bu sözler, Osmanlıların da oldukça benimsediği "tabiî sınır" ayırımına işaret etmektedir. Yani, Gümüşhane'nin yukarı kısmıyla aşağı kısmının tarihi serüvenleri doğal olarak birbirinden ayrıdır. Üstelik aynı farklılık, sosyo-kültürel bakımdan da bir vâkıadır. Aşağı Dere Karadeniz Bölgesi'yle, Yukarı Dere de Doğu Anadolu Bölgesi'yle benzeşmektedir. Bu gerçekler tarihî vakalardan ortaya çıkmış olgulardır. O halde Gümüşhane tarihi incelenirken; Aşağı Dere, Trabzon ve burayı hakimiyetinde bulunduran devlet/devletlerle ilgili olarak açıklanabilir. Yukarı Dere ise, Doğu Anadolu'ya hakim olmuş devlet/devletlerle ilişkilendirilebilir. Burada, Aşağı-Yukarı Dereler'in nerelerden ibaret olduğuna değinmek gerekmektedir. Halkın kullandığı tabirler, bugünkü Gümüşhane'nin içerdiği köyler dikkate alındığında; Aşağı Dere denilen yerin, Akçakale Boğazı'ndan Zigana Dağı'na kadarki bölüm, Yukarı Dere'nin de söz konusu boğazdan Vavuk Dağı'na uzanan kısım olduğu tespit edilmektedir ${ }^{42}$. Nitekim bu husus, Osmanlılar'ın bölgeyi fethinden sonra yaptıkları tahrir (=-yazım) defterlerinin kayıtlarında da hemen aynıyla görülebilmektedir. 1479 yılında fethedilen

\footnotetext{
12 Bu sınır, yüzeysel olarak bazı yaynlarda da yer almışur. Anthony Bryer-David Winfield, The Byzantine Monuments and Topography of the Pontos, Washington, 1985, Volume, I, 49. p.
} 
Torul, Cezire ve Canehah kaleleri ${ }^{43}$, Gümüşhane'nin hemen yanındaki Canca Kalesi'nden Kürtün-Torul hatuna kadarki bölgeyi ihtiva etmektedir. 1461 'da Osmanlılarca fethedilen Trabzon sınırlarına sonradan kaulan bu bölgenin ilk tahriri, 1486 yılına aittir ${ }^{44}$.

Yukarı Dere'ye gelince; halk söyleyişinde, Akçakale Boğazı'ndan Vavuk Dağı'na kadarki saha olarak tanımlansa bile, Yağmurdereli ahalinin "Koğans Köyleri" adıyla andığı yerler, bahsedilen Yukarı Dere'dir. Koğans köyleri ise, Akçakale Boğazı'ndan sonraki ilk köy olan Selseki (Tekke)'den başlayarak Varyemez Köyü'ne kadar devam eden köyler olup; doğudan Yağmurdere, baudan Kelkit köyleriyle sınırlıdır. Bu sahanın aşağısı Torul, yukarısı da Bayburt köyleriyle çevrilidir. Nitekim Gümüşhane'nin Yukarı Dere kısmı, 15161518 tarihleri arasında yapılan ilk Osmanlı tahrir defterlerinde de, anıldığı gibi Selseki'den başlayarak Varyemez'e kadar devam eden sahayı ihtiva etmekte olup; Kökes nahiyesine bağlıdır ${ }^{45}$.

Yukarıdaki açıklamalardan da anlaşılacağı üzere, Gümüşhane tarihinin iki kısımda mütalâa, edilmek zorunluluğu ortaya çıkmaktadır. Araştırmamıza konu olan iki mezar anıtı da, söz konusu Yukarı Dere'de olduğundan Doğu Anadolu tarihiyle ilişkilendirilmek durumundadır. En azından tarihi veriler bu ihtimali kuvvetlendirmekte ve hatta hemen hiç araşturılmamış bu bölgenin -şimdilik- böyle değerlendirilmesini gerektirmektedir.

Bu aşamada, mezar anıtı hakkında söylenen, Karamanoğullarından Pir Ahmed' $\mathrm{e}^{46}$ ait olduğu şeklindeki rivayeti hatırlama durumundayız ${ }^{47}$. Mezar

${ }^{43}$ Ibn Kemal, Tevarih-i Äl-i Osman, VII. defter (Yayına hazırlayan: Serafettin Turan), Ankara, 1991, 464-467. s.

${ }^{14}$ M. Hanefi Bostan, XV-XVI. Asırlarda Trabzon Sancağında Sosyal Ve Íktisadî Hayat (Marmara Üniversitesi Türkiyat Enstitüsü Basılmamış Doktora Tezi), İstanbul, 1993, 13-19. sayfalarda, ilk tahrir ve bunun içerdiği idari birimler, aynen zikredilen Aşağı Dere'ye tekabül eder.

45 İsmet Miroğlu, XVI. Yüzyılda Bayburt Sancağı, 86-93. sayfalarda Kövans Nahiyesi'ne tâbi kōyler zikredilmektedir. Ancak Kovans'in en bau köyü olan Selseki (Tekke) Köyü okunamamışur. Halbuki, Miroğlu'nun eserinde bir kaç köyün vakfedildiği gösterilen Çağırgan Baba Zaviyesi, Selseki (Tekke) Köyü'ndedir. "Karye-i Selseki (سلسككي)nâm 'an-nahiye-i Kökes timâreş be-zaviye-i Çağırgan Baba der-karye-i mezkûre". BOA., TD., 60 nr., 228. s. Diğer yandan, nahiyenin en doğu sınırında bulunan Varyemez Köyü, bugünkü Kocayokuş Köyü'ne bağlı ve tamamıla Gülmahmutoğulları'na ait aynı adla amılan arazidir. Șimdi Bayburt'a bağı Çerçi Kōyü ile sımırdır. Varyemez Köyũ ile ilgili bu not, Selahattin Tozlu'dan ōğrenilmiştir.

${ }^{\dagger i}$ Karamanoğlu Pir Ahmed, İbrahim Bey'in oğludur. Abu Bakr-i Tihrani, Kitab-1 Diyarbakriyya (Yayınlayanlar: Necati Lugal-Faruk Sümer), II. C.. Ankara, 1993, 554. s.; Gaffar Totaysalgır. Karaman (Lârende) Tarihi İncelemeler, Konya, 1944, 19. s., 1. dipnot.; Ernst Diez vd., Karaman Devri Sanatı, İstanbul, 1950, 87. s.; M. Mesud Koman, Şikarî'nin Karamanoğulları Tarihi, Konya, 
anıtının içindeki kitabenin tarihi de yanlış okunmuştur. Bu rivayetin yanında, maddî verilere bakıldığı takdirde, Karamanoğulları devri eserleriyle paralellikler de göze çarpmaktadır. Paralelliklerden birinin, mezar anıtı girişinin, basık kemerli ve çıkıntılı üzengi taşlarına sahip olmasıdır ${ }^{48}$. Ancak, basık kapı kemerlerinin çıkıntılı üzengi taşlarına oturması, Anadolu Selçuklu

1946, 191. s.; M. Zeki Oral, "Fatih Sultan Mehmed'in Gevala Kalesi ile Karaman Ellerini Fethi ve Hâmidī'nin Terci-i Bendi" VD., IV, Ankara, 1958, 81. s.; I. Hakkı Uzunçarşılı, Anadolu Beylikleri Ve Akkoyunlu, Karakoyunlu Devletleri, 30. s.

${ }^{47}$ Karamanoğlu Pir Ahmed, kardeşleri ve Fatih Sultan Mehmed ile yaptuğı mūcadeleler sonunda, Akkoyunlu hükümdarı Uzun Hasan'a sığınmışur. Abu Bakr-i Tihrani, a.g.e., II. C., 567. s.; Gaffar Totaysalgır, a.g.e., 23. s.; 1. Hakkı Uzunçarşılı, Anadolu Beylikleri, 34. s.

Karamanoğlu Pir Ahmed'in, Silifke yakınlannda, Osmanlılarla mücadele ettiği Minan Kalesi'nin, Osmanlılar tarafından fethedilmesinden sonra intihara teşebbüs ettiği, ancak bu teşebbüsten yaralı olarak kurtulduğu ve Uzun Hasan'ın yanına gittiği, kendisine dirlik olarak verilen Bayburt'ta oturduğu ve az zaman sonra hastalanarak, 874/1470 tarihinde öldūğü ifade edilmiştir. İ. Hakkı Uzunçarşılı, Anadolu Beylikleri, 34. s.; Osmanlı Tarihi, II. C., 107. s.

S. Özcan San, yapının Karamanoğlu Pir Ahmed'e ait olduğunu ifade edenlerdendir. Gūmüşhane Kültür Araşturmaları Ve Yöre Ağızları, Ankara, 1990, 626. s. San, ayrıca; Karamanoğlu Pir Ahmed'in, Akkoyunlu hükümdarı Uzun Hasan'a sığındığım, onun, Akkoyunlulara yaptı̆̆ı hizmetlerden dolayı da, kendisine Gümüşhane'nin Yeniyol, Pir Ahmed, Tekke, Kızılkōy ve şimdiki Özcan Mahallesinde "yurt" verildiğini ifade etmiştir. S. Özcan San, "Gümüşhane Müstakil Sancağındaki Mahalleler Aileler Ve Efsaneler, Hikayeler", Geçmişte Ve Günümüzde Gümüşhane Sempozyumu (13-17 Haziran 1990), 137. s.

Ayrıca, kümbetin içindeki kitabenin tarihinin, 957 (1550) olduğu ve yapının Karamanoğlu Pir Ahmed'e atfedildiği de vakidir. Gülyüz Uslu, Gümüşhane Ve Cevresinin Tarihi ve Sanat Eserleri, İstanbul, 1980, 28. s.; "Gümüşhane'nin Tarihçesi Ve Turistik Değerleri", Geçmişte Ve Gümümūzde Gūmūşhane Sempozyumu (13-17 Haziran 1990), 151. s.

48 Arel, basık kapı kemerlerinin çıkıntılı üzengi taşlanına Karaman devri özelliği olarak belirlemiştir. Mehlika Arel, "Mut'taki Karamanoğullan Devri Eserleri" VD., V, Ankara, 1962, 245. s. Arel'in bu tespitine, Karaman Devri sanatunda, değişik biçimlerde olmak üzere; Ermenek Tol Medrese (1339), Karaman Hacıbeyler Camii (1358), Karaman Arapzade Camii (1374-1420) taçkapılarında rastlanılmaktadır. Ernst Diez vd., a.g.e., 22., 48., 57. sekiller. Bu tespiti mezar anıtları açısından ele alacak olursak, sadece Mut Hocendi (Büyük) Türbesi'nde var olduğunu görürüz.

Kaldı ki, Anadolu Selçuklu medreselerinden; Seyitgazi Ümmūhan Hatun Medresesi (XIII. yüzyıl başları), Atabey Ertokuş Medresesi (1224), Akşehir Taş Medrese (1250), Kırşehir Cacabey Medresesi (1272), Sivas Buruciye Medresesi (1271), Cay Yusuf bin Yakub Medresesi (1278) taçkapılarında da biçimleri farklı da olsa kullamıldığı görülür. Aptullah Kuran, Anadolu Medreseleri, I, Ankara, 1969, 156., 72., 199., 120., 235., 130. R.

Yine Anadolu Selçuklu devrindeki bazı cami, han ve mezar amıtlarımın kapılarında da bu tarz çıkıntular uygulanmıştur. Kayseri Külük Camii (1210-1211), Niğde Alaeddin Camii (1223), Kayseri Hunat Hatun Camii (Bat kapısı) (1237-1238), Susuz Han (Burdur-Antalya) (XIII. yüzyılın ortaları), Akhan (Denizli-Konya) (Avlu kapısı) (1254), San Han (Kayseri-Aksaray) (XIII. yüzyılın sonu), Kayseri Dōner Kümbet (XIII. yüzyılın sonu), Niğde Hüdavend Hatun Kümbeti (1312-1313), Niğde Gũndoğdu Kümbeti (1344), Kayseri Ali Cafer Kümbeti (1349-1350) gibi. Rahmi Hüseyin Ünal, Osmanlı Öncesi Anadolu-Türk Mimarisinde Taçkapılar, İzmir, 1982, 10. 18., 40., 55., 59., 95., 118., 120., 124., 125. R. 
sanatunda; farklı yerlerde ve zamanlarda yapılmıs medrese, cami, han ve mezar anıtlarında da görülmektedir. Bu nedenle, basık kapı kemerlerinin çıkıntılı üzengi taşlarına sahip olmalarını, sadece Karamanoğulları eserlerine atfetmek mümkün görünmemektedir.

Karamanoğullarının mezar anıtlarına bakuğımızda, gövde biçimi ve üst örtüsü açısından üç mezar anıtı ile paralellik kurulabilir ${ }^{49}$. Görüleceği üzere, gövde ve üst örtü bakımından benzerliklerde dahi nüanslar vardır. Konya Fakih Dede Türbesi'nde tuğla malzemenin kullanılmış olması da bir farklılık olarak göze çarpmaktadır. Bezeme elemanları bakımından, Karamanoğulları yapılarında kullanılmış olan herhangi bir motif benzerliği aramak, incelediğimiz mezar anıtında, tahrip edilmiş de olsa hiç bir bezeme unsurunun bulunmayışı nedeniyle kendiliğinden ortadan kalmaktadır. Ayrıca şunı ifade etmekte yarar vardır. Kare prizmal gövdeli mezar anıt geleneği sadece Karamanoğullarına ait olmadığı gibi, Anadolu Türk sanatına da özgü değildir ${ }^{50}$. XII. yüzyılın sonundan önce Anadolu'da görülmeyen bu tarz mezar anıtları, XIII. yüzyılın başlarından itibaren, çok seyrek olmakla beraber her bölgede rastlanabilen bir tip haline gelmiştir ${ }^{51}$. Kısaca Pir Ahmet Köyü'ndeki Anonim Kümbeti'in, Karamanoğullan mezar anıtları ile biçim ve malzeme farklılıklarını dikkate aldığımızda, rivayetle fazla bağdaşmadığı görülmektedir. Böylece, rivayetin, yeni veriler elde edilinceye kadar bu halde kalacağı anlaşılmaktadır.

Eserin bulunduğu bölgenin, Osmanlılar tarafından fethini hatırlarsak, cenazeliği bulunan bir mezar anıtının, Osmanlılarla ilgisinin olmayacağı kolaylıkla kabul edilebilir.

1: Bunlardan birincisi, Karaman-İbrahim Bey Türbesi (829-868/1426-1462): Kare gö̀deli olan bu anutun gövdesi yukarı kısımda sekizgene dōnüştürülerek bir kasnak oluşturulmuştur. Piramidal külahı sekiz yüzeylidir. Alt katun giriși, üst kat merdivenlerinin alundandır. Ernst Diez vd., a.g.e., $67-81$. s.

Ikincisi, Konya-Fakih Dede Türbesi $(860 / 1454)$ : Kare gövdenin yukarısındaki sekizgen kasnağın üzerindeki piramidal üst örtünün malzemesi tuğladır. Ernst Diez vd., a.g.e., 136. s. Alt katının olup olmadığımı adı geçen yayndan anlamak mümkūn olamamışur.

Üçüncüsü, Mut-Küçük Türbe (1444'den ōnce): Kare gövdeli yapunın üst örtüsü piramidal kūlâhtır. Alt katumın mevcut olduğu, girişinin belli olmadığı, muhtemelen dışta olan girişin toprak seviyesinin yükselmesiyle kapanmış olabileceği ifade edilmiştir. Mehlika Arel, a.g.m., 244. s.

5) O. Cezmi Tuncer, a.g.e., 157. s.

51 M. Oluş Arık, "Erken Devir Anadolu Türk Mimarisinde Türbe Biçimleri" Anadolu (Anatolia), XI, (1967), Ankara, 1969, 95. s. 
Bu durumda, mezar anıtının, Akkoyunlularla ilişkisinin varlığına bakmanın yararlı olacağı akla gelebilir ${ }^{52}$. İncelediğimiz mezar anıtının üzerinde Akkoyunlulara ait olabileceğine işaret eden herhangi bir iz yoktur. Ancak, Akkoyunlu mezar anıtlanı açısından bir karşılaştırma yapacak olursak, şöyle bir sonuca varabiliriz: Görüleceği üzere Akkoyunluların bilinen ilk mezar antu, Bayburt'un Sinür Köyü'ndeki Kutlu Bey Türbesi'dir. Kutlu Bey Türbesi'nin, ilk türbe olması yanında, incelediğimiz mezar anıtına en yakın Akkoyunlu türbesi oluşunu ve bu türbede çininin dahi kullanılmış olmasını dikkate aldığımızda, her iki mezar anıtının farklılıkları ortaya çıkmaktadır. Kutlu Bey Türbesi'nde cenazeliğin bulunmayışı ve diğer Akkoyunlu mezar anıtlarından cenazeliği bulunanların, cenazelik girișlerinin yeri de, Pirahmet'teki kümbetin mezar odası girişi ile bağdaştığı söylenemez. Anonim Kümbeti'in, cenazeliğinin üst örtüsünün inşa biçiminin arkaikliği ve malzemesinin genel durumu bakımından Akkoyunlu mezar anıtlarından ayrıldığı görülür. Kümbet, yalınlığı bakımından, muhtemelen Akkoyunlu eseri olabileceği ifade edilmiş olan; Diyarbakır Şeyh Abdülcelil ve Lala Bey Türbesi ile yakınlığı vardır biçiminde bir yaklaşım getirilebilirse de, onların Akkoyunlularla

${ }^{52}$ Akkoyunlu mezar anıtlarına bakuğımızda, karşımıza şöyle bir tablo çıkmaktadır: Bayburt-Sinür Köyü Kutlu Bey Türbesi (1389 civarı): Sekizgen gōvdeli yapı, kubbeyle örtülmüştür. Amıtun cenazeliği yoktur. Ayrıca bu yapıda çini kullanıldığı, ancak şimdi bunların ortadan kalkuğı ifade edilmiştir. A. Șeref Beygu, a.g.e., 255. s.; Gōnül Güreşsever-Ara Altun, "Bayburt Köylerinde Türk Mimari Eserleri", Sanat Tarihi Yıllığı, III. Sayı, İstanbul, 1970, 46. s., 6. plan; Metin Sózen, Anadoluda Akkoyunlu Mimarisi, İstanbul, 1976, 146. s., 46. şekil.

Akkoyunlu mezar anıtları içinde kare prizmal gòvdeli olan yoktur. Diğer mezar anıtları için bkz., İbrahim Artuk, "Mardin'de Akkoyunlu Hamza'nın Mezarı", Selçuklu Araşurmaları, I (1969), Ankara, 1970, 157. s.; Yılmaz Önge, "Iğdır'ın Amarat (Çakırtaş) Köyü'ndeki Kümbet", Önasya, V.C., 55. Sayı, Ankara, 1970, 8-9. s.; "Ahlat Emir Bayırdır Kümbeti ve Mescidi", Ōnasya, V.C., 59-60. Sayı, Ankara, 1970, 6-7 s. Ara Altun, Mardin'de Türk Devri Mimarisi, İstanbul, 1971, 106. s.; Oktay Aslanapa, Türk Sanat, I-II, Ankara, 1990, 319-320. s.

Bir de Akkoyunlu mimarîsi dahilinde olması muhtemel mezar antlanı vardır ki, bunların sayısı iki olup, Diyarbakır'da bulunmaktadırlar. Bu mezar anıtları şunlardır: Şeyh Abdülcelil Türbesi (XV. yüzyıl ortaları veya XVI. yüzyıl başları): Kesme taştan inşa edilmiş olan türbe; sekizgen gövdeli, içten kubbe, dıştan oluklu kiremit kaplı piramidal bir üst örtüye sahiptir. Metin Sõzen, a.g.e., 158. s.; 51. șekil. Beysanoğlu, tarih belirtmemekle birlikte, Akkoyunlu dōneminden olduğunun kabul edildiğini ifade etmiştir. Şevket Beysanoğlu, Anıtlan ve Kitabeleriyle Diyarbakur Tarihi, II. C., Ankara, 1990, 469. s.

Lala Bey Türbesi (XV. yüzyılın ortası-XVI. yüzyılın başı): Kesme ve moloz taştan yapılmış olan türbenin gōvdesi, kare prizmal olup kubbeyle örtülmüştür. Güneydeki kapıdan inilen, yalın görünüşlü cenazeliği beșik tonozludur. Metin Sözen, a.g.e., 159. s.; 23. şekil. Sōzen, bir başka yayınında bu eseri XVI. yüzyılın ilk çeyreğine tarihlemiştir. Metin Sözen, Diyarbakır'da Türk Mimarisi, İstanbul, 1971, 281. s. Beysanoğlu ise eseri, XV. yüzyıla vermiştir. Şevket Beysanoğlu, a.g.e., II. C., 468 . s. 
ilişkisi tam kurulamadığı için verimli bir sonuç alınabileceğinden emin olmak güçtür.

Erzincan beyi Mutahharten'in, Eretnaoğullarının ve Celayirlilerin; mezar anıtının bulunduğu bölgedeki hakimiyetlerinin kısa oluşları, onlardan herhangi birisi tarafından, böyle bir eserin inşasının gerçekleştirilebileceği konusunda tereddüt uyandırmaktadır.

Moğolların Anadolu'daki hakimiyetleri sırasında, Bayburt'un Anadolu Selçuklularına bağlı kaldığı yukarıda ifade edilmişti. Bu durum, Moğolların, burada hiç bir eser ortaya koymadıkları biçiminde anlaşılmamalıdır. Moğolların, Bayburt'ta, daha çok eğitim ve öğretimle ilgili yapılar inşa ettikleri bilinmektedir ${ }^{53}$.

Eserlerin bulunduğu bölgenin Mengücüklüler ve Saltuklular arasında sınır olabileceğini belirtmiştik. Mengücükoğullarının ortaya koyduğu mezar anıtlarına bakarsak, bunların sekizgen olduklarını görürüz ${ }^{54}$.

Konya Selçuklularını doğrudan ilgilendiren kare kaideli bir mezar anıtı olarak, Sivas'ta, I. İzzeddin Keykavus'un $614 / 1217$ 'de inşa ettirdiği darüşşifanın, güney eyvanında bulunan türbesi görülmektedir ${ }^{55}$. Bu türbenin, medresenin eyvanının, sonradan değiştirilerek elde edildiği bilinmektedir. Malzemesi, bezemesi, medresenin çatısından sonraki ongen gövdesi bakımından, incelediğimiz mezar anıtıyla herhangi bir ilgi kurmak mümkün olmamaktadir.

Konya Selçuklularından önce, bu bölgenin hakimi olan Saltukluların mezar anıtlarını dikkate aldığımızda, ortak noktaların çoğaldığı gözlemlenmektedir $^{56}$. Bu ortak noktalardan bir tanesi en ilgi çekenidir. $\mathrm{O}$ da, cenazelik girişinin; anıtın üst katuna girişi sağlayan kapıdan içeri girilince, hemen aşağıya inen merdivenlerle sağlanmış olmasıdır. Bu şekildeki cenazelik girişleri, Türk sanatunda, Anadolu dışında, İran'daki Burc-u Demavend Kümbeti'nde ${ }^{57}$, Anadolu'da ise, biçimi farklı olsa da orijinal olarak sadece Erzurum'-

${ }^{53}$ Rahmi Hüseyin Ünal, "Monuments İslamiques Pre-Ottomans de la Ville de Bayburt et de ses Environs" Revue des Etudes İslamiques, XL/1, Paris, 1972, 100 s.

${ }^{54}$ Oktay Aslanapa, Türk Sanat, I-II, 249-250. s.

55 Oktay Aslanapa, Türk Sanau, I-II, 253-254. s.

50 Saltuklu mezar anıtlarıyla; iki kath oluşu, tamamen taş melzemenin kullamılması yanında, cenazeliğin girişi bakımından şimdiye kadar tek örnek olarak bilinen, Emir Saltuk Kümbeti'nin cenazelik girişiyle olan benzerliğidir.

57 Aslanapa, Burc-u Demavend Kümbeti'nin tarihini, üslûp bakımından XI. yüzyılın üçüncü çeyreğine vermiştir. Oktay Aslanapa, Türk Sanat, I-II, 68. s.; O. Cezmi Tuncer, üst örtüsünü dikkate alarak, XII. yüzylın ilk yarısm önermiştir. O. Cezmi Tuncer, a.g.e., 40.s. 
daki Emir Saltuk Kümbeti'nde ${ }^{58}$ görülmektedir. Bununla birlikte incelediğimiz mezar anıtının; kare prizmal gövdeli oluşu, dış örtünün kasnaksız olarak $^{59}$, doğrudan duvarlara oturması ve dört yüzeyli piramidal dış örtüye sahip olması; Diyarbakır Sultan Şüceaddin Kümbeti $(605 / 1208-9)^{60}$, Ahlat Şeyh Necmeddin Kümbeti $(619 / 1222-1223)^{61}$ ve Erzurum'da Üç Kümbetler'in batusındaki Anonim Türbe ${ }^{62}$ ile benzerlik göstermektedir. Kullanılan malzemenin taş olmasıyla da benzerlikleri vardır.

Buraya kadar verilen bilgileri gözönünde tutarak, incelediğimiz mezar anıtunı, Erzurum Emir Saltuk Kümbeti'nin mezar odası girişiyle olan paralelliğine rağmen, Saltuklulara atfedebilecek daha başka bilgi elde edilememiştir. Diyarbakır Sultan Şüceaddin Kümbeti, Ahlat Şeyh Necmeddin Kümbeti ve Erzurum Emir Saltuk Kümbeti'nin batısındaki Anonim Kümbeti dikkate

58 Ünal, Erzurum-Emir Saltuk Kümbeti'nin tarihini, bezemedeki bazı unsurlardan yola ç1karak, XI.-XII. yūzyl olarak kabul etmiştir. Rahmi Hüseyin Û̉nal, Les Monuments İslamiques Ancien de la Ville D'Erzurum et de sa Region, XL/1, Paris, 1968, 108. s., Fig. 95-96.; Önkal, banisinin İzzeddin Saltuk olabileceği ve mimarî ôzelliklerinden yola çıkarak XII. yūzylın ortalanı önermektedir. Hakkı Önkal, a.g. tez, 21. s., 3. Sekil; Tuncer ise, anıtun tarihini, İzzeddin Saltuk adından yola çıkıp, 1190 'lar olarak belirlemenin daha doğru olabileceğini belirtmiştir. O. Cezmi Tuncer, a.g.e., 126. s.; Aslanapa, Erzurum Kale Mescid'ni ve mezar anıtunın üslûbunu dikkate alarak, XII. yüzyılın sonuna verilebileceğini ileri sürmüştür. Oktay Aslanapa, Türk Sanat, I-II, 251. s. Üst kattan mezar odasına girişi olan bir diğer mezar anıt, Kayseri-Pazarören Melik Gazi Türbesi (XII. yüzyılın sonlañ)' dir. Ancak, asıl girişinin, dışta, üst kat merdivenlerinin altunda olduğu, üst kattan mezar odasına girişi sağlayan kısmın sonradan yapıldığı ortaya konulmuştur. Tahsin Özgüç-Mahmut-Akok, "Melikgazi Türbesi Ve Kalesi", Belleten, XVIII. C., 69-72. Sayı, Ankara, 1954, 332. s.; Hakkı Önkal, a.g.tez., 286. s.; O. Cezmi Tuncer, a.g.e., 156. s.

${ }^{59}$ Kare prizmal gōvdenin üzerine çokgen kasnak ve piramidal kūlâh örtūlü ilk õrnek olarak Tokat-(Ebu'l Kasım) Ali Tusî Türbesi (1234) bilinmektedir. M. Oluş Arık, "Erken Devir Anadolu-Türk Mimarisinde Türbe Biçimleri", 75. s.; Ancak, Kayseri-Pazarören Melikgazi Kümbeti'nin, Tokat -Ali Tusî Türbesi'nden daha eski olduğu da ifade edilmiştir. $O$. Cezmi Tuncer, a.g.e., 249. s.; Bu tarz mezar anıtlarının diğer örneklerinin isimleri ve tarihleri konusunda bkz. O. Cezmi Tuncer, a.g.e., 157. s.; Halit Çal, Niksar'da Türk Eserleri, Ankara 1989, 55-56. s.

${ }^{60}$ O. Cezmi Tuncer, a.g.e., 102. s.; "13. Yüzyıla Ait Ǘç Kümbet", Sanat Tarihi Yillığı, VI (1974-75), Istanbul, 1976, 91. s.; Hakkı Önkal, a.g. tez., 302. s.

${ }^{61}$ M. Oluş Arık, a.g.m., 74. s.; O. Cezmi Tuncer, a.g.e., 70. s.; Hakkı Önkal, a.g.tez., 302. s.; Oktay Aslanapa, Türk Sanat, I.-II, 265. s.

${ }^{62} \mathrm{Bu}$ mezar anıtunın yapımı, Tuncer'de iki farkh tarih olarak kaydedilmiştir. Birincisinde, ihtimal dahilinde XIII. yüzyll ortaları; ikincisinde XIV. yüzyl verilmiştir. O. Cezmi Tuncer, a.g.e., 122. ve 157. s.; Önkal ise, XIII. yüzylın ilk çeyreğini bir ihtimal olarak görmektedir. Hakkı Önkal, a.g. tez, 304. s.

Bu yapı, Tuncer tarafından tek kath ifade edilirken, kazı sonrasındaki haliyle bilgi veren Ōnkal'da iki katı olduğu belirtilmiştir. O. Cezmi Tuncer, a.g.e., 121. s.; Hakkı Ốnkal, a.g. tez. 302. s. Türbenin çevresi, gũnümüzde, iki kathılığı gōrülücek biçimde düzenlenmiştir. 
alarak bunların malzemelerini, iki katlı oluşlarını, kare prizmal gövdelerini ve dört yüzeyli piramidal külâhlarının kasnaksız olarak doğrudan duvara oturmalarını dikkate aldığımızda, Pirahmet Köyü'ndeki Anonim Kümbet'le benzerliklerini ortaya koymuş oluyoruz. Ayrıca, incelediğimiz mezar anıunın; alt kat üst örtüsünde, buraya inen merdivenin basamaklarında ve üst katun dış örtüsünde -harç sıvanın alundan görünen- kullanılan malzemelerin alelâde oluşu, mezar anıtının arkaikliğine verilerek, XII. yüzyılın ikinci yarısı ile XIII. yüzyılın başları, bu yapınının inşa tarihi olarak kabul edilebilir.

\section{TEKKE BELDESI ÇAĞIRGAN BABA TÜRBESI}

Yeri: Çă̆ırgan Baba ${ }^{63}$ Türbesi, Tekke Beldesi'nin ${ }^{64}$ Bayburt girişinde, sağdaki mezarlığın ana yola yakın tarafında ve hemen yanında bulunmaktadir.

Tarihçesi: Türbe, asıl kısmın girişinin yukarısındaki, $0.25 \times 0.41 \mathrm{~m}$. ölçülerindeki, taş üzerine sülüsle, iki satur halinde yazılmış kitabesine göre, Receb 990/Temmuz-Ağustos 1582 tarihinde inşa edilmiştir ${ }^{65}$. Vakıflar Genel

${ }^{63}$ Cağırgan Baba'nın kimliği konusunda herhangi bir bilgi elde edemedik. Osmanlı kaynaklarında, 1516-1518'de, Cağırgan Baba Zaviyesi'nin zaviyedarı Dervis Ali'dir. BOA., TD., 60 nr., 228 s. 1530 ylında ise şeyhliğini elinde Cağırgan Baba'nın torunlarından Ahmed Han oğlu Derviş Sah Hüseyin, zaviyenin şeyhliğinielinde bulunduruyordu. BOA. TD. $966 \mathrm{nr} ., 280$. s.

Zaviyenin vakıf kōyleri şunlardır: Şurut (Kabaktepe), Güvercinlik, Hor-ı Ulyâ (Beyçam), Hor-1 Süflâ (Gökdere). BOA., TD., 60 nr., 208-228. s. İsmet Miroğlu, XVI. Yüzyılda Bayburt Sancağı, 84-88 s.

Cağırkanlı/Çă̆ırganlı, bir Akkoyunlu Türkmen oymağının adıdır. H. Bostan, a.g. tez, 8889. s.

int Köyün adı konusunda; asılları Dişhekimi Cetin Işık'ta olan belgelerden, 1207 h. tarihlisinde سـلك Selke; 1281 h. tarihlisinde سينكي Singi; 1284 h. tarihlisinde 1287 tarihli olanda Selka Tekye olarak geçmektedir. Bu bilgiler, Selseki'nin şimdiki Tekke Beldesi olduğu konusunda şüpheye yer bırakmaz Ancak, belgelerde geçiyor olmakla beraber, anılan isimlerden Selseki ve Tekke dışında kalanlar, büyük ihtimalle yazım hatası veya zamanla halk sōyleyişindeki farklılıktan kaynaklanıyor olmalıdır. Belgelerin kullanılması konusunda Dişhekimi Çetin Işık'a teşekkür ederim.

Tekkeli halk ozam Soydaş. Tekke adlı şiirinin bir dörtlūğünde, Tekke'nin diğer adlanm;

"Kale yıkuntusı gördüm bedende

Dört isim değişmiş kayıth bende

Selseki Sindi Tekke lisanda

Seydi'si var Tekke Köyūn İçinde"

şeklinde sıralamışur. Hasan Soydaş, Gỏnül Bağımdan Şiirler, Gümūşhane, 1991, 101.s.

${ }^{65}$ Yukarıda numaraları verilen tapu defterlerinde mezar anıunın varlığına herhangi bir nedenle de olsa işaret edilmemiştir. Ancak, zaviye şeyhleri vefat edince, genellikle, zaviyelerinin 
Müdürlüğü Arşivi'nde Çağırgan Baba Vakfiyesi yoktur. Tekke Beldesi'yle ilgili olarak, Gümüşhane fihristinde, sadece "Tekke Köyü Cami-i Şerifi"nin şahsiyet kaydı mevcuttur. Türbenin, önce, içten kubbe dıştan piramidal külâhla örtülü bölümü inşa edilmiştir. İçten düz örtülü, dıştan kırma çatılı olan kısım ise sonradan eklenmiştir. Ama ne kadar sonra ve ne zaman eklendiği bilinmemektedir. Bu durum iki bölümün birleştiği yerdeki dilitasyondan da anlaşılmaktadır. Bu kısmın çausı, 1968-1969 tarihlerinde inşa edilmiştir ${ }^{66}$. Yapı, en son, 1991'de Vakıflar Genel Müdürlüğü tarafindan "adi tamir" türünden onarılmıştır ${ }^{67}$. Kitabesindeki ifadeden, türbenin, Çağırgan Baba adına yaptırıldığı anlaşılmaktadır. Yapının kitabesi şu şekildedir (4. Resim):

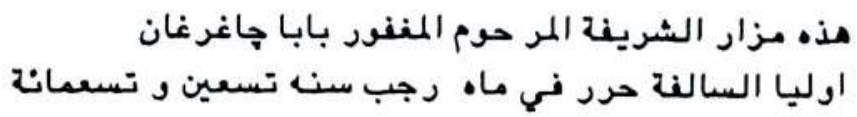

Hâzâ mezarü'ş-şerif el-Merhûm el-mağfûr Baba Çağırgan

Evliya es-sâlife hurrire fi mâh-1 receb sene tus'în ve tus'a mie ${ }^{68}$.

Mimarî Özellikleri: Türbe iki kısımdan oluşmaktadır (3. Çizim). Sonradan ilave olunduğunu ifade ettiğimiz kısmın girişi güney duvarında, $0.96 \mathrm{~m}$. genişliğindedir. Düz lentolu girişin batısında bulunan dikdörtgen pencere, bu mekânın ışık aldığı tek açıklıktır (5 Resim). Bu bölüm düzgün olmayan kesme taşlarla inşa edilmiştir. Duvarlarından kuzey ve batı taraftakiler düzgün kesme taşla kaplanmıştır. Duvarların kalınlıkları her üç yönde farklı olup; güneyde $0.60 \mathrm{~m}$., batıda $0.75 \mathrm{~m}$., kuzeyde ise $0.80 \mathrm{~m}$. ölçülerindedir.

çevresine gõmüldükleri bilinmektedir. Bu durumda, Çağırgan Baba'nın olduğu bilinen mezarın üzerine, bu türbenin, kitabede belirtilen tarihte inşa edildiği kabul edilir.

Ünlü seyyahımız Evliya Çelebi'nin seyahatnamesinde bahsettiği Çă̆ırkanlı Dede Ziyareti, Bayburt'un içindedir. Bu ziyaret konumuzun dışında kalmaktadır. Türbenin, 990/1582 tarihli kitabesinin varlığına, Gülyüz (Akagün) Uslu dikkat çekmiştir. Gülyüz (Akagün) Uslu, a.g.e., 29. s.; a.g.m., $151 \mathrm{~s}$.

${ }^{66}$ Bu bilgi Dişhekimi Çetin Ișık'tan alınmıştur.

${ }^{67} \mathrm{Bu}$ onarımda; türbenin çevresi hafredilmiş, çevresine moloztaş duvar örülmüs, bunun üzerine yonu taşı harpuşta yapılarak demir parmaklık konulmuştur. Türbe kūlâhındaki bozulmuş olan yonu taşları sōkülüp, aslına uygun olarak ve orijinal taşlardan da órnekler bırakarak kūlâh elden geçirilmiştir. Türbenin önündeki giriş kısmının ahşap çatusı yapılmış ve üzeri bakırla kaplanmıştır. Yapının içindeki sıvalar raspa edilmiş ve yeniden sıvanmıştur. VGMA., 29.01.01/4 nr. dosya, Türbenin incelendiği Haziran 1996'da bütün bunların gerçekleştirilmiş olduğu anlaşılmışur.

${ }^{68}$ Kitabe, şu şekilde açıklanabilir: Bu mezar-ı şerif, eski velilerden biri olan Baba Cağırgan'indır. 990 yılı Receb aynda yazıldı. 
Mekânın ahşap olan üst örtüsü, dıştan, semerdam biçiminde düzenlenmiş ve bakırla kaplanmıştır. Duvarlar, içten harçla sıvanmış ve kireçle badanalanmıştur. Hiç bir bezemenin bulunmadığı bu mekânın, daha önceden herhangi bir bezemeye sahip olup olmadığını kaynaklardan öğrenemedik. Burada bulunan ahşap sandukanın kenarları tașlarla tespit edilmiştir. Sandukanın kime ait olduğu bilinmemektedir. Ancak, Çağırgan Baba'nın yakınlarından birisine ait olması muhtemeldir.

İlk inşa edilmiş olan bölüme ise, birinci kısmın doğu tarafına düşen, dış yandan düz lentolu, içten basık kemerli, $0.73 \mathrm{~m}$. genişliğindeki bir kapıdan geçilir (6. Resim). Kapının yan sövleri ince tutulurken, üst tarafi yekpare kalın bir lentoyla belirlenmiştir. Lentonun yukarısında içinde kitabenin bulunduğu, sivri kemerli, hafif içerlek bir alınlık yeralır. Alınlık kemerinin kilit taşında yuvarlak bir rozet bulunmaktadır. Rozetin ortasında; bir yuvarlak, bunun çevresinde ise, geometrik bir düzenleme veren bitkisel bezeme vardır. Yapıdaki tek bezeme unsuru da bu rozettir. Mekân, yaklaşık $4.70 \times 4.70 \mathrm{~m}$. ölçülerinde bir karedir. Burası, köşelerde sivri kemerli tromplara oturan bir kubbeyle örtülüdür. Duvarlar, tromplar ve kubbenin içi harçla sıvanmış ve kireçle badanalanmıştır. Bunların yüzeylerinde hiç bir bezeme yoktur. İçerideki, yalın ahşap sandukanın baş ve ayak taşı yoktur. Yani sandukanın Çağırgan Baba'ya ait olduğunu gösteren net bir veri bulunmamaktadır. Bu durum mezarın, Çă̆ırgan Baba'ya ait olmayacağı biçiminde anlaşılmamalıdır. Çünkü, kitabesindeki ifadeler, mezarın Çağırgan Baba'ya ait olduğuna işaret etmektedir. Bu bölüm dıştan, yaklaşık olarak $6.20 \times 6.20 \mathrm{~m}$. ölçülerindedir. Tamamen düzgün kesme taştan inşa edilmiş olan bu kısım; güney duvarında bulunan, dıştan; biri düz lentolu diğeri basık kemerli, içten her ikisi de düz lentolu, yere oldukça yakın tutulmuş iki pencereden ışık almaktadır (7. Resim). Kübik gödenin köşeleri, dışta, içteki trompların dışa yansımalarıyla kesilerek üst kısım sekizgene dönüştürülmüştür. Oluşturulan sekizgen, kubbe kasnağı biçiminde biraz yükseltilmiştir. Daha sonra üst örtü, dıştan, hazırlanan sekizgen kasnağa uygun olarak piramidal bir külâhla kapatılmıștır. Bu örtünün kilidindeki alem, yalın bir taştır (8. Resim).

\section{DEĞERLENDIRME VE SONUÇ}

Yukarıda tanıtılan iki mezar anıtından Pirahmet Köyü'ndeki Anonim Kümbet çok küçük ölçülere sahiptir. Bununla birlikte anıun yalın olduğu gözlemlenmektedir. Tarihleme yapılırken Anadolu'daki diğer mezar anıtlarıyla, farklı yönlerden karşılaşurma yapıldığı için, burada ayrıca bir değer- 
lendirme yapılmayacaktur. Şu ana kadar yayınlara Pir Ahmed Türbesi olarak geçen bu mezar anıtunın, Anadolu'da Türkler tarafindan kurulmuş olan beylikler ve devletlerin mezar anıtlarıyla, bilhassa Karamanoğullarının eserleri ve Karamanoğlu Pir Ahmed ile olan ilişkisini ortaya kolduktan sonra, anıtın bir anonim eser olarak ele alınmasının daha uygun olacağı ortaya çıkmaktadır. Biz de bu nedenle, mezar anıtını "Anonim Kümbet" olarak adlandırdık.

Bu mezar anıt Anadolu'daki Türk mezar anıt mimarîsine; plân, gövde biçimi, üst örtü şekli, malzeme ve bezeme yönünden herhangi bir yenilik getirmemektedir. Yani bilinen örneklerin tekrarından bir tanesidir. Ancak, mezar anıtunın alt kat girişinin, üst kattan sağlanması ve üst kat girişinin hemen önündeki açıklıktan aşağıya inilmesi noktasında, genel Türk sanat içinde bilinen iki örnek olan, İran'daki Burc-u Demavend ve Erzurum-Emir Saltuk Kümbeti'nin yanında üçüncüsü olmasıyla önem kazanmaktadır. Dolayısıyla Erzurum-Emir Saltuk Kümbeti alt kat girişi konusunda kabul gören, "Anadolu'daki ilk ve son örnek" ifadesi değerini yitirmektedir. Bu aşamada, Erzurum-Emir Saltuk Kümbeti alt kat girişinin ilk ve son örnek olması konusunda bir görüş ifade edebilmek pek mümkün görünmemektedir. Fakat, Anadolu Türk sanatında, orijinal olarak, bu tarz cenazelik girişi olan mezar anıt sayısının ikiye çıktı̆ı kabul edilmelidir. Ayrıca, şimdiye kadar, daha fazla incelendiği kabul edilen Anadolu Selçuklu sanatu konusunda, Anadolu'nun yine de bakir olduğu ortaya çıkmaktadır.

Tekke Beldesi'ndeki Çă̆ırgan Baba Türbesi'nin önündeki ek kısmının orijinal olmadığını ifade etmiştik. Orijinal olan kısım ise kare bir mekândır. Burası, kullanılan malzemesi, köşelerdeki tromplan ve iç örtünün kubbe olmasıyla Osmanlı mezar anıtlarıyla paraleldir. Ancak üst örtüsünün dıştan görünüşü bakımından Osmanlı mezar anıtlarıyla uyum içinde olduğu söylenemez. Köşelerdeki trompların dışa yansımaları, bu yansımalardan sonra oluşturulan sekizgen kasnak ve kasnağa göre şekillendirilen sekiz yüzeyli piramidal üst örtü, o tarihlerdeki Osmanlı mezar anıtlarında görülmeyen bir biçimdir. Adı geçen eserin bu noktada mahallî etkiler altında kaldığını görmekteyiz. Yakın çevresine bakıldığında, Bayburt'taki Anonim Kümbet (XIV. yüzyll sonu-XV. yüzyl başı) ${ }^{6 !}$ ile bir çok yönden benzerlik göstermektedir. Bu iki eser arasında her ne kadar 100 yıldan fazla bir zaman olsa da, kullanılan malzemesi, plânı, kubbeyi taşıyan trompların dışa yansımaları ve üst örtünün şekli bakımından paralellikler vardır. Yalnız Bayburt Anonim Kümbet'te,

${ }^{61}$ R. Hüseyin Ünal, a.g.m., 15-16. figür, VI-b planche. 
kasnak çok yüksek tutulmuş olup, bu durumuyla Tekke Beldesi Çağırgan Baba Türbesi'nden ayrılmaktadır.

Tekke Beldesi Çağırgan Baba Türbesi'nin, Osmanlı mezar anıtı mimarîsine bir yenilik getirdiğini söylemek mümkün değildir.

Birbirine, yaklaşı $5 \mathrm{~km}$. mesafede ve ayrı dönemlere ait bu iki mezar anıtından; Tekke Beldesi Çăğrgan Baba Türbesi, yakın zamanda tamir edildiği için varlığını uzun süre devam ettirme şansına sahiptir. Pirahmet Köyü'ndeki Anonim Kümbet ise tamire muhtaç durumdadır. Bu yapının da ilgili kurumlar tarafından en kısa zamanda tamir edilerek, ömrünün uzatılması konusunda bazı adımlar atılacağı ümit edilmektedir. 

Kasmm Ince

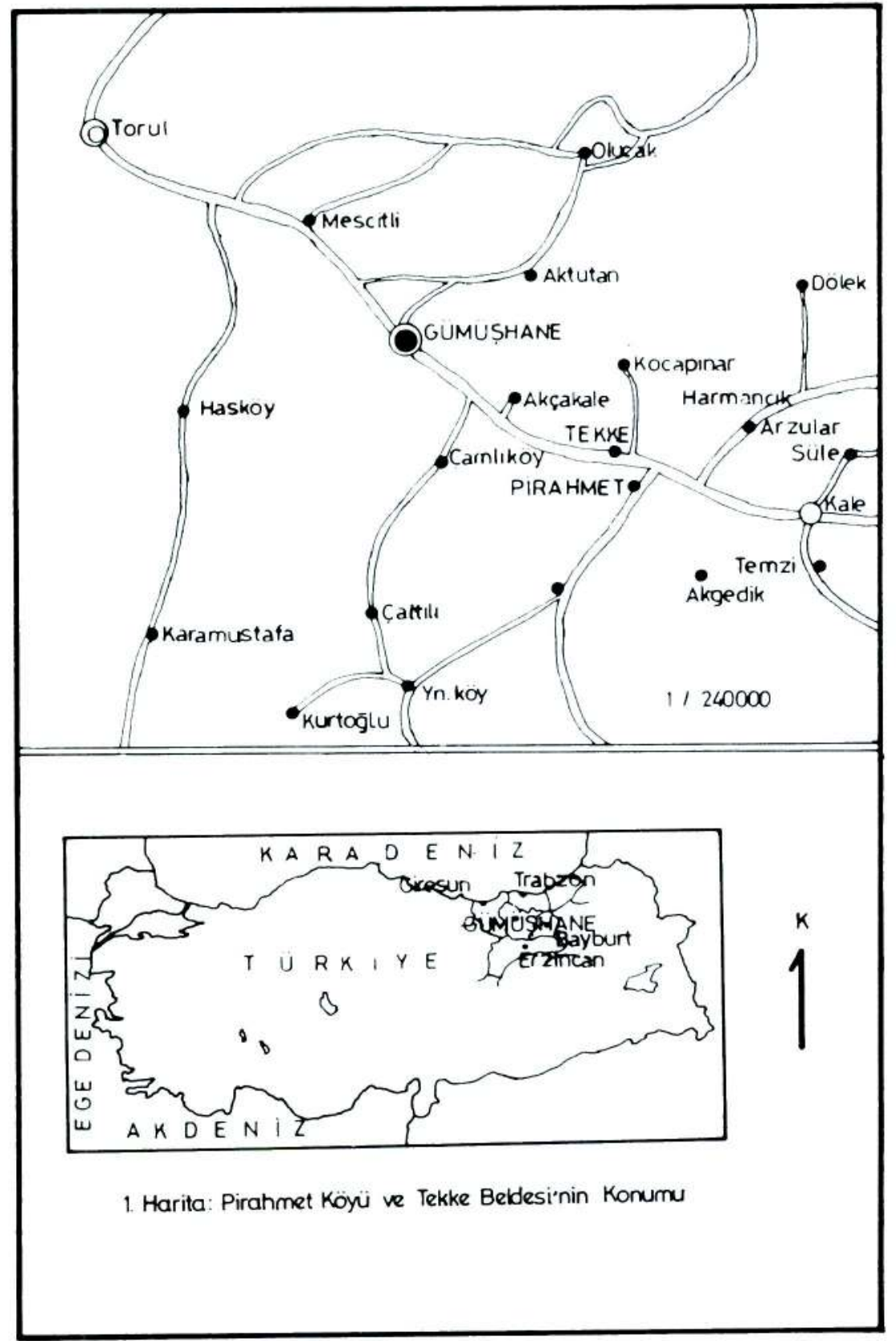




\section{Kasim Ince}
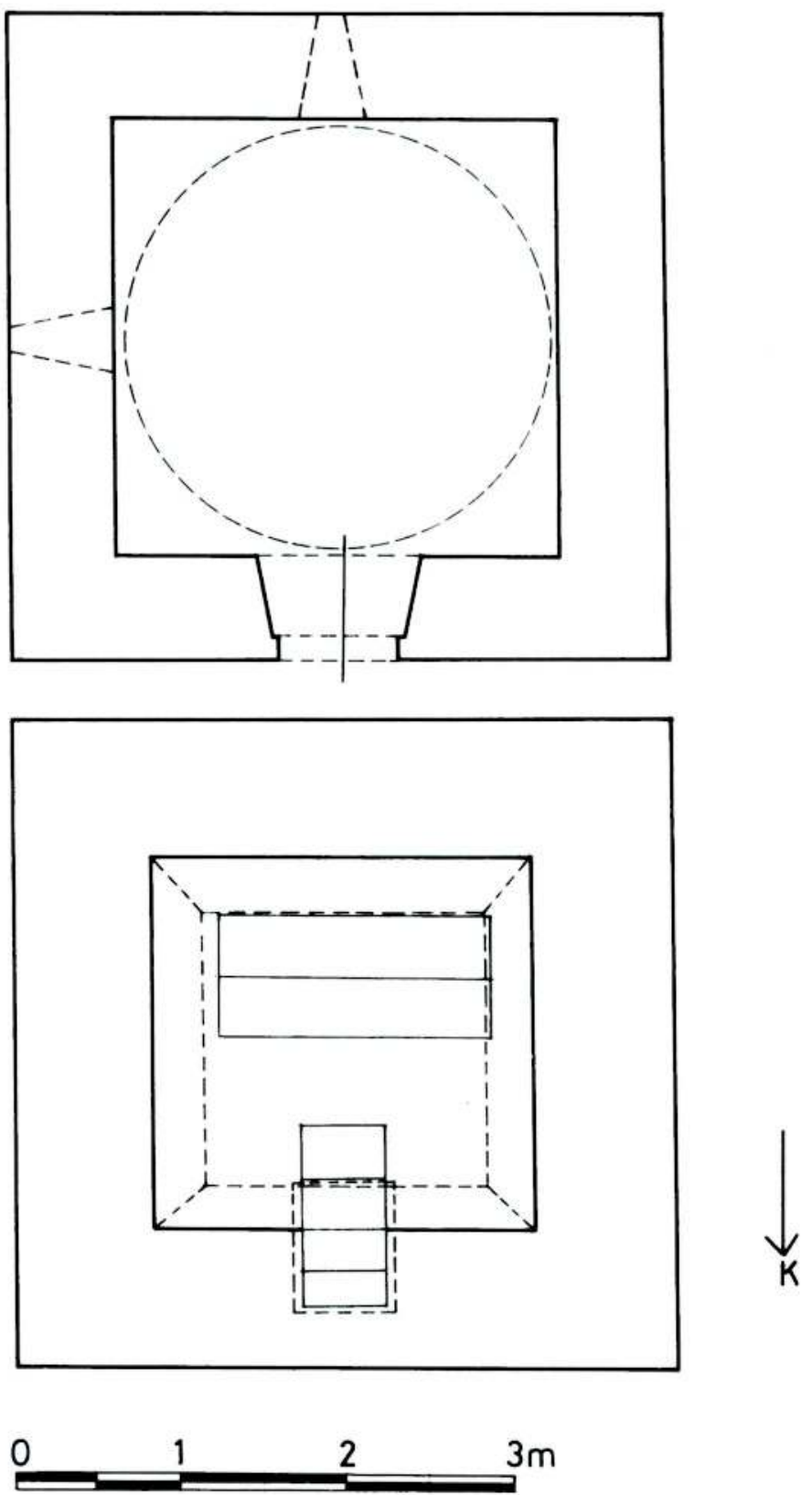

Çizim 1: Gümüşhane-Pirahmet Kōyü Anonim Kümbeti'nin Plan. 
Kasm Ince

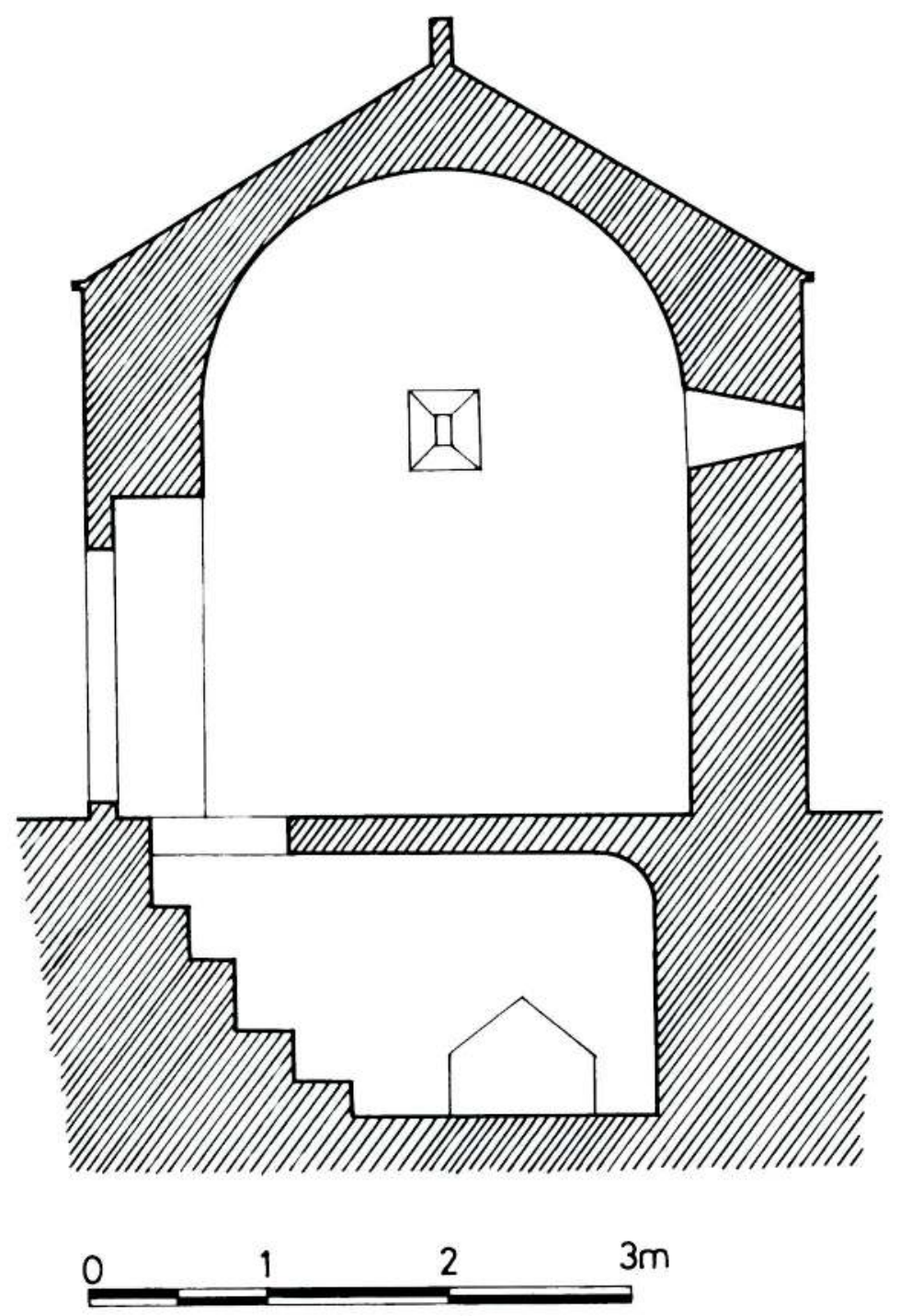

Çizim 2: Gümüşhane-Pirahmet Kòyü Anonim Kümbet'in Kesiti. 
Kasim Ince
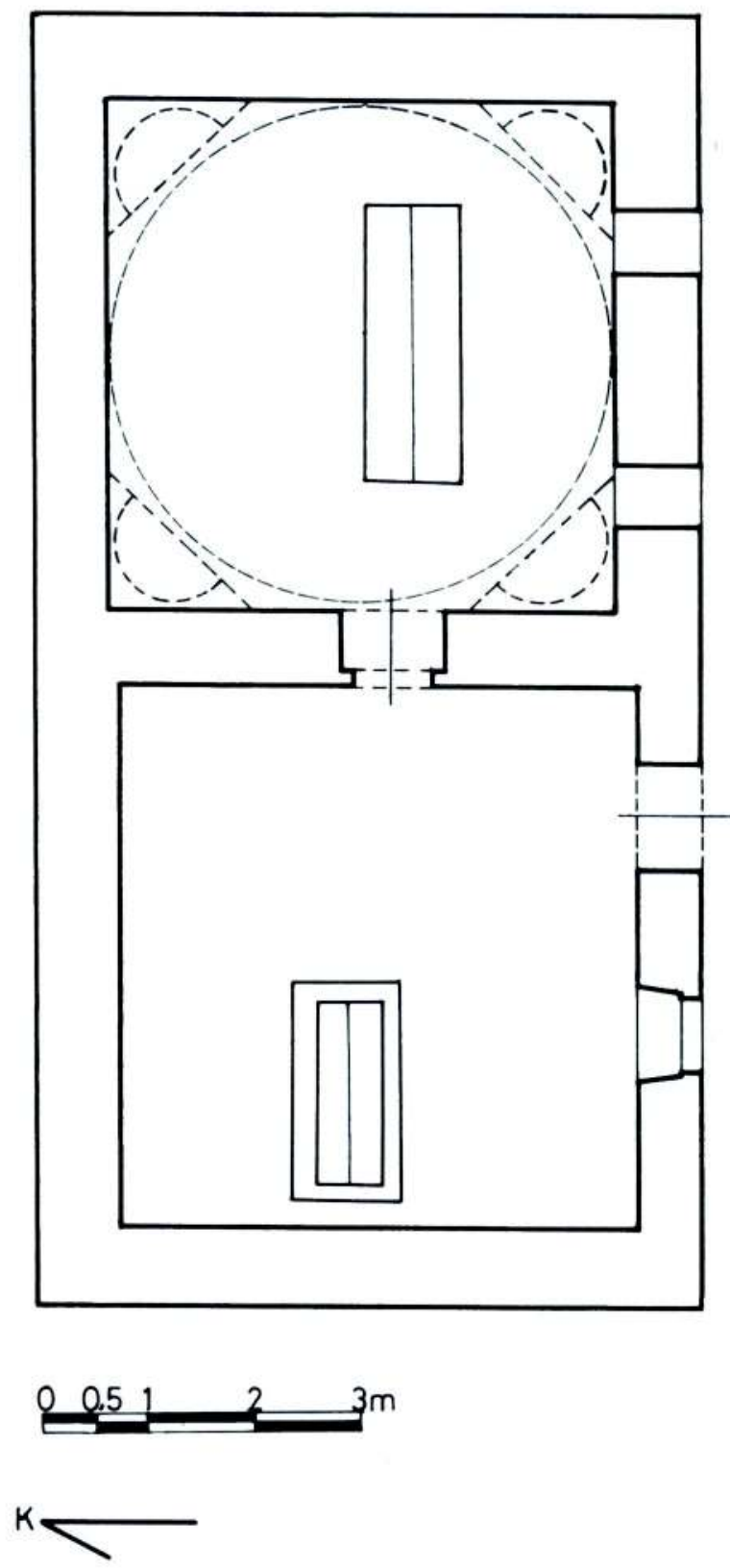

Çizim 3: Gümüşhane-Tekke Beldesi Çağırgan Baba Türbesi'nin Planı 


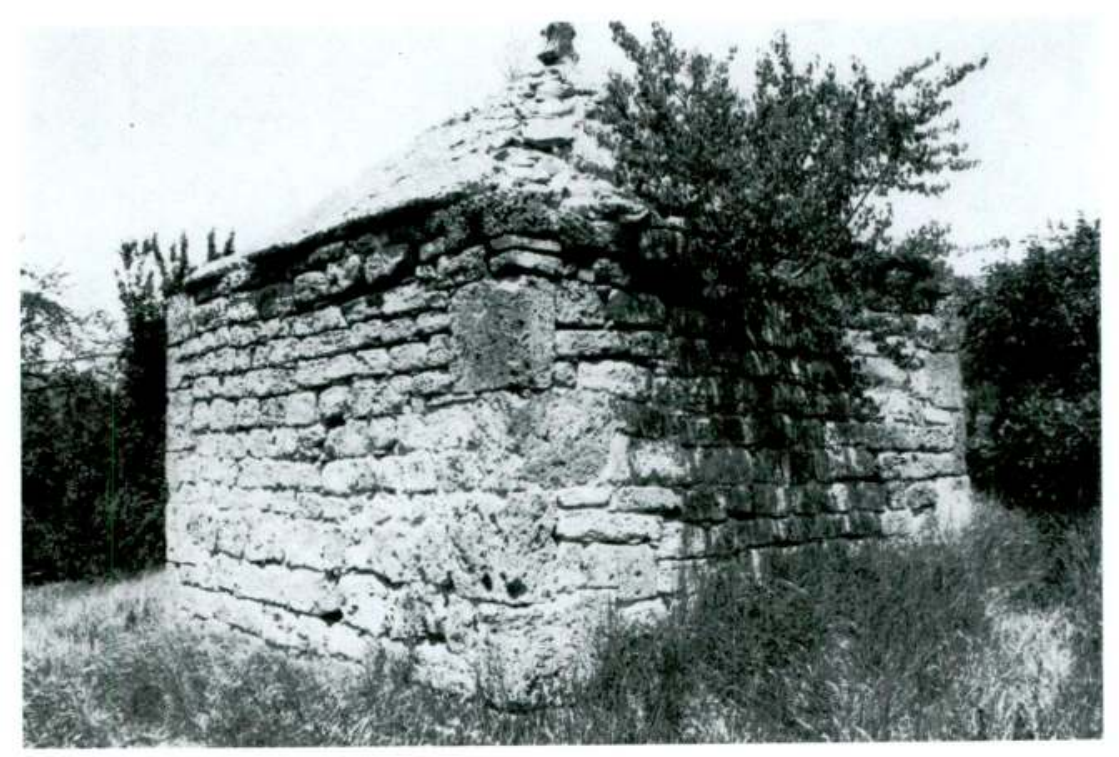

Resim 1

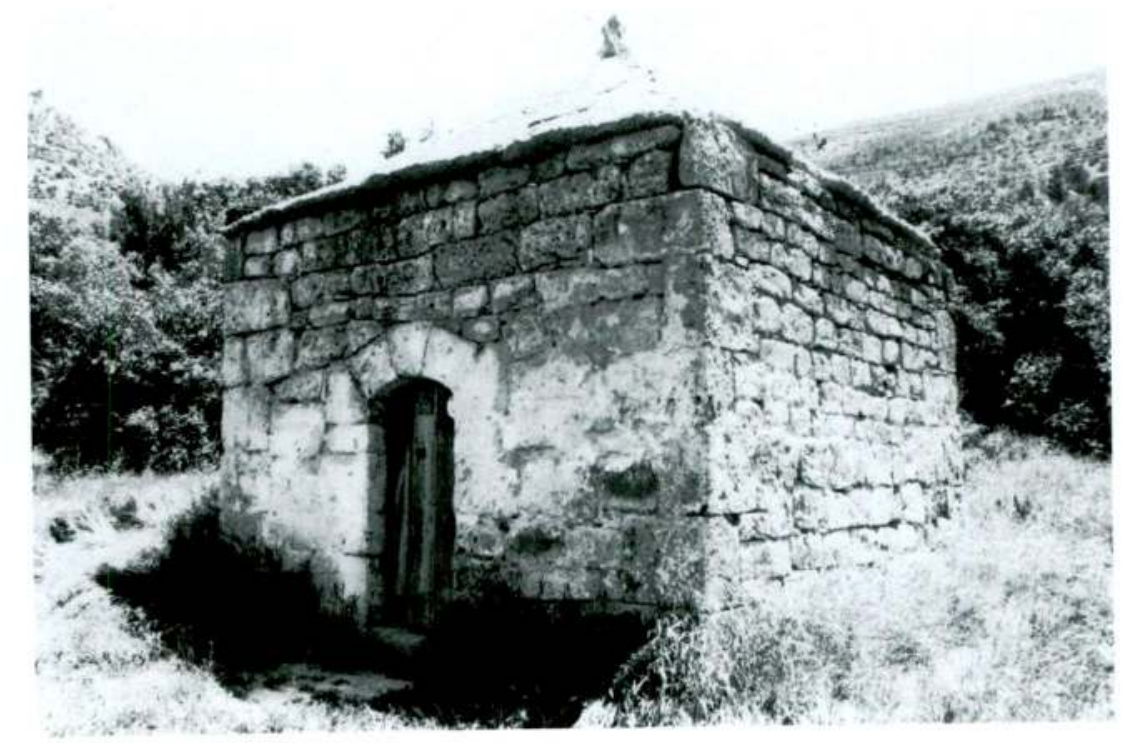

Resim 2 


\section{Kasım İnce}

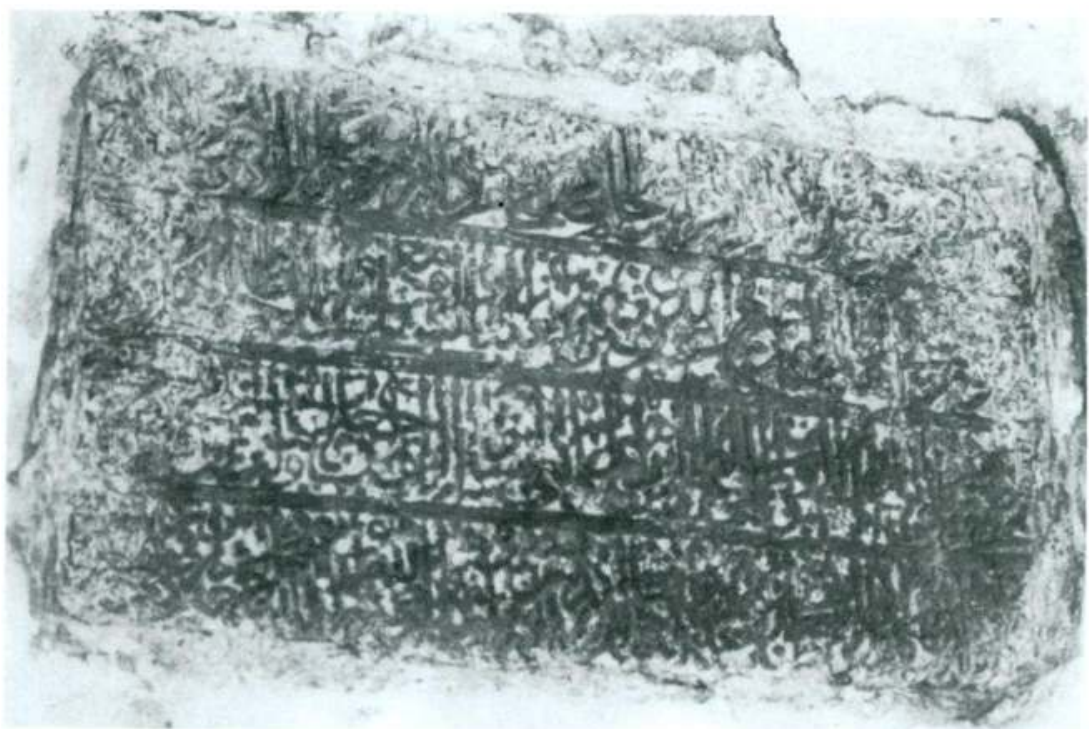

Resim 3

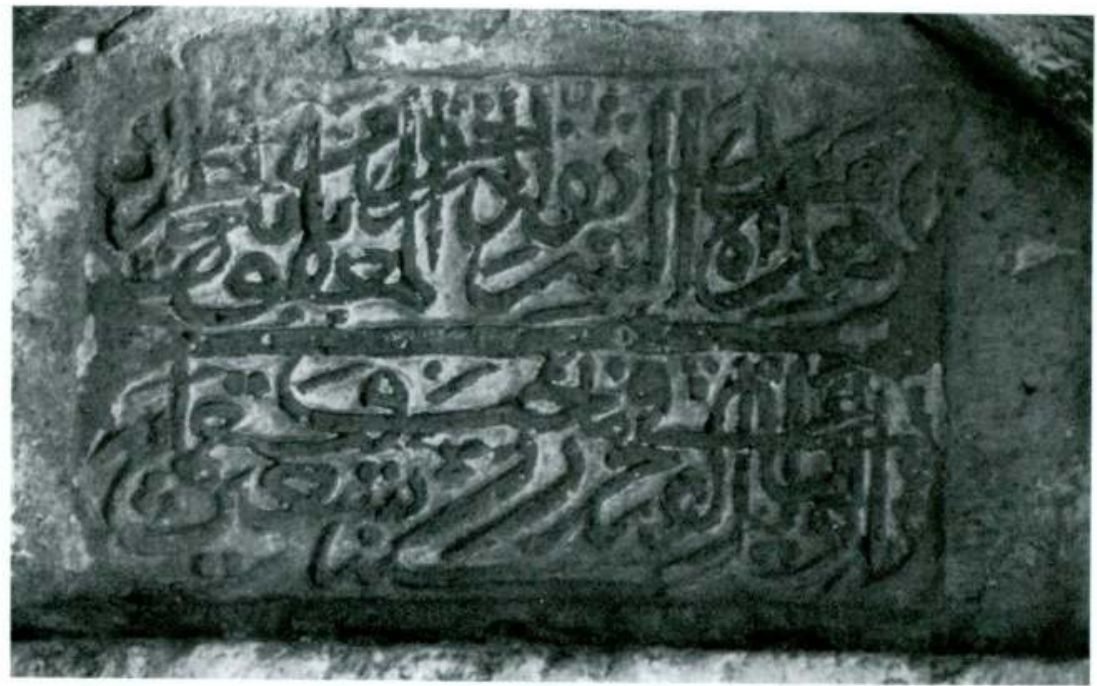

Resim 4 


\section{Kasım Ince}

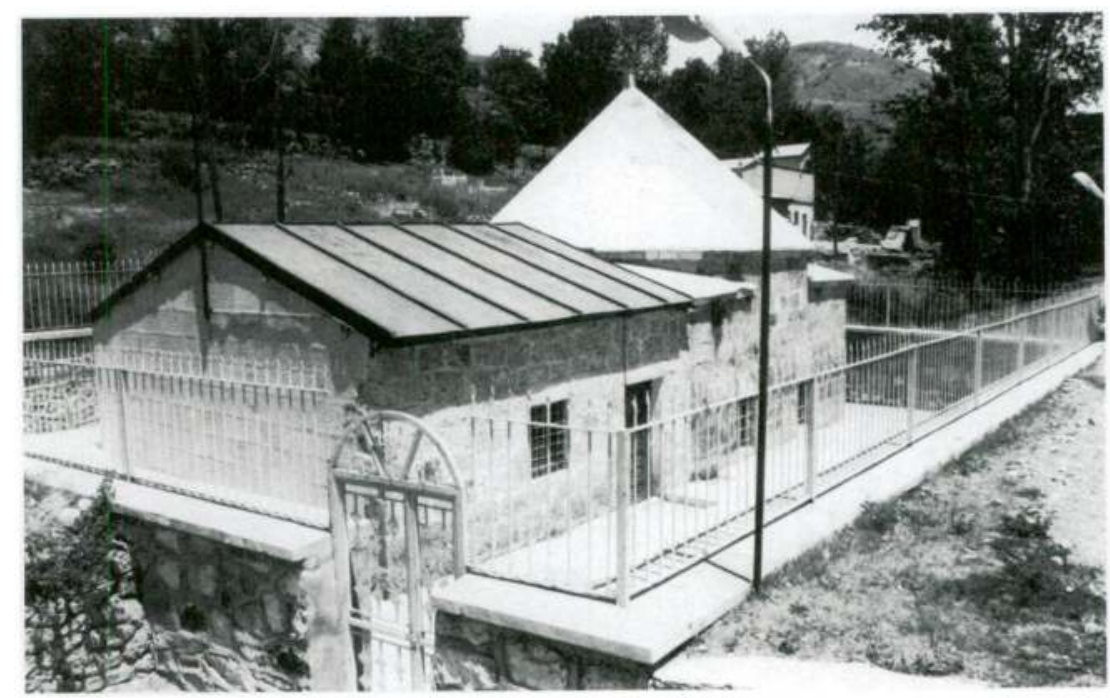

Resim 5

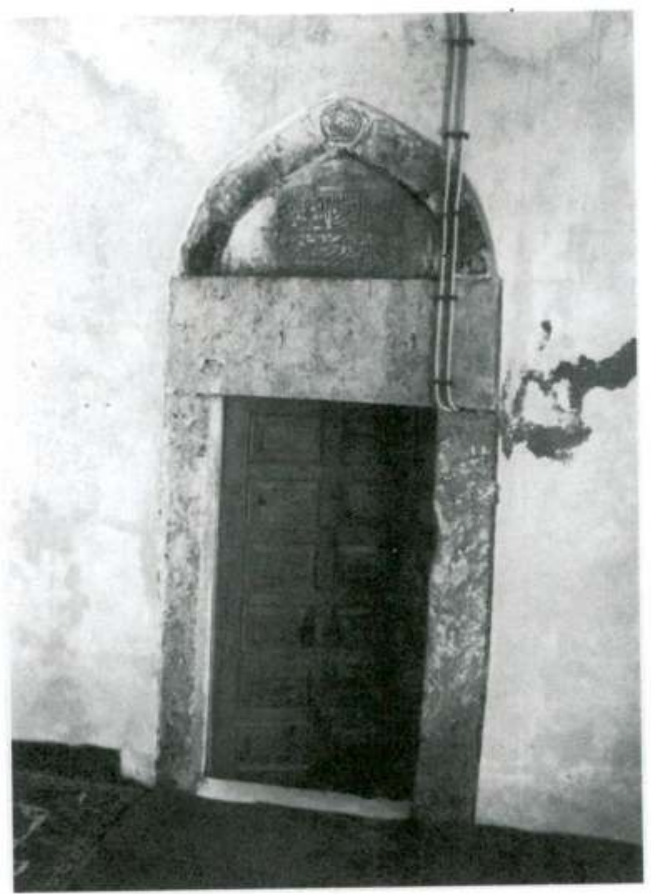

Resim 6 


\section{Kasım Ince}

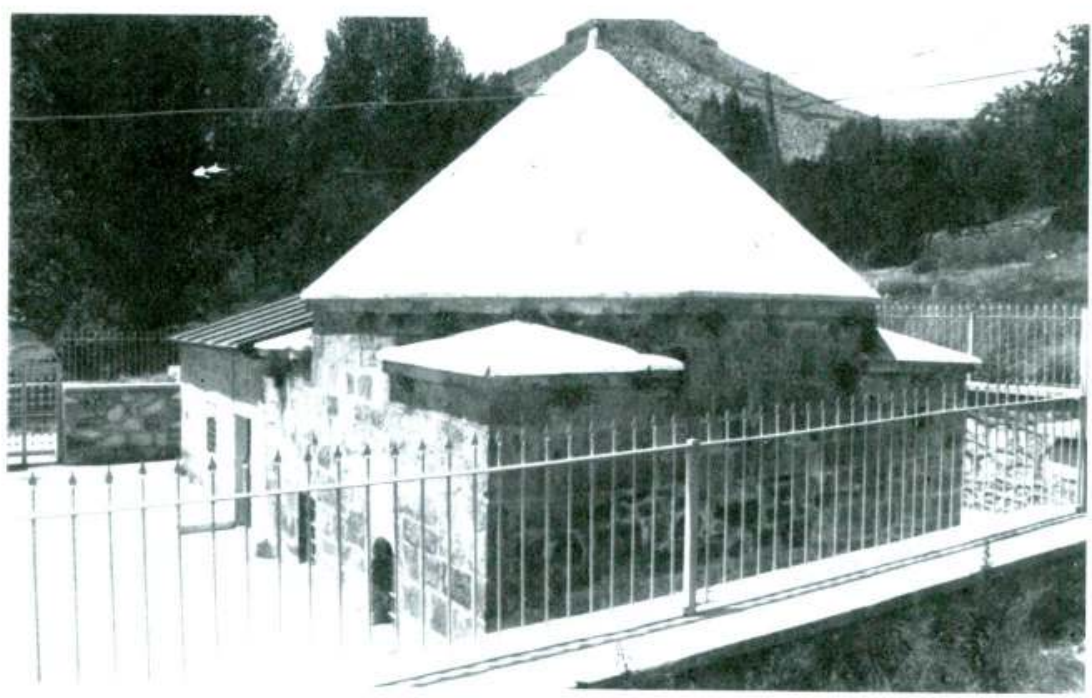

Resim 7

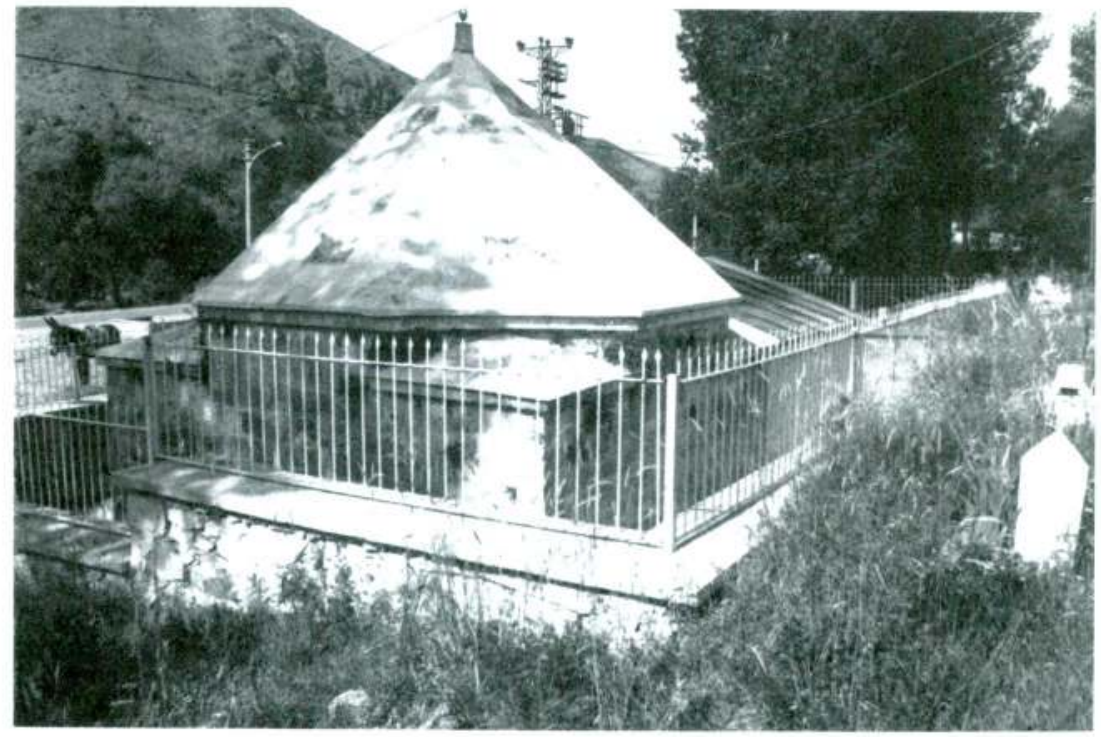

Resim 8 